\title{
Integrative description of Mesobiotus anastasiae sp. nov. (Eutardigrada, Macrobiotoidea) and first record of Lobohalacarus (Chelicerata, Trombidiformes) from the Republic of South Africa
}

\author{
Denis V. TUMANOV ${ }^{1,2}$ \\ ${ }^{1}$ Department of Invertebrate Zoology, Faculty of Biology, Saint Petersburg State University, 199034, \\ Universitetskaya nab. 7/9, Saint Petersburg, Russia. \\ ${ }^{2}$ Marine Research Laboratory, Zoological Institute of the Russian Academy of Sciences, 199034, \\ Universitetskaja nab. 1, Saint Petersburg, Russia. \\ Email: d.tumanov@spbu.ru
}

urn:1sid:zoobank.org:author:49E22A70-C27B-485B-941E-577666EE65F9

\begin{abstract}
A new species of the genus Mesobiotus is described from the Republic of South Africa using a traditional morphological approach (light and scanning electron microscopy) combined with molecular analysis (18S rRNA, 28S rRNA, ITS-2 and COI markers). Mesobiotus anastasiae sp. nov. differs from all known Mesobiotus species by having a unique combination of characters of the adult animals and the eggs. Adults of the new species have an oral cavity armature without elongate teeth in the second band, while the processes of the egg chorion have a basal collar and distinct rows of large pores. An updated key to the species of the genus Mesobiotus, including 66 of 70 currently described species, is given. An aquatic mite species from the Lobohalacarus weberi complex (freshwater Halacaridae) co-occurs with M. anastasiae sp. nov., suggesting that the newly described tardigrade inhabits constantly wet moss cushion habitats.
\end{abstract}

Keywords. Tardigrada, Macrobiotidae, molecular taxonomy, new species, key to species, freshwater Halacaridae, new record.

Tumanov D.V. 2020. Integrative description of Mesobiotus anastasiae sp. nov. (Eutardigrada, Macrobiotoidea) and first record of Lobohalacarus (Chelicerata, Trombidiformes) from the Republic of South Africa. European Journal of Taxonomy 726: 102-132. https://doi.org/10.5852/ejt.2020.726.1179

\section{Introduction}

The Tardigrada Doyère, 1840 is a phylum of microscopic multicellular animals widely distributed in nature. Currently there are more than 1300 species described (Degma et al. 2009-2020), but this is very likely an underrepresentation of the actual number of taxa, as the global diversity of tardigrades is poorly investigated (Bartels et al. 2016).

The tardigrade fauna of the Republic of South Africa is the most investigated on the African continent (Middleton 2003; McIness et al. 2017). However, the current state of knowledge is far from complete. Among 46 tardigrade species reported from the Republic of South Africa (McIness et al. 2017; 
Meyer et al. 2018; Stec et al. 2020), 22 records (48\%) belong to poorly described species, or members of (semi-)cryptic species complexes, whose attribution needs verification. To date, only one species of South African tardigrade (Minibiotus ioculator Stec, Kristensen \& Michalczyk, 2020) was described using an integrative approach, including light and scanning electron microscopy investigation, as well as sequencing of molecular markers (Stec et al. 2020).

In 2008 I received a few moss samples collected in the Republic of South Africa. One of these samples contained a new species of the genus Mesobiotus Vecchi, Cesari, Bertolani, Jönsson \& Guidetti, 2016. Currently this genus includes 69 species (Kaczmarek et al. 2020; see also Tumanov 2018b and Tumanov \& Pilato 2019), being the second-largest genus in the family Macrobiotidae Thulin, 1928. A recent integrative redescription of M. harmsworthi (Murray, 1907), the type species of the genus (Kaczmarek et al. 2018), gave a powerful impetus for further research on the real diversity of Mesobiotus. To date, however, only a small fraction of its species have been genetically characterized, so phylogenetic relationships within the genus remains poorly resolved (Kaczmarek et al. 2020).

In this paper, I describe a new Mesobiotus species using integrative taxonomy. The detailed morphological description is supplemented by DNA sequences of four standard genes used in tardigrade taxonomy and phylogenetics (the nuclear 18S rRNA, 28S rRNA, ITS-2, and the mitochondrial COI).

An aquatic mite species of the genus Lobohalacarus Viets, 1939 (freshwater Halacaridae Murray, 1877), belonging to the Lobohalacarus weberi complex was also found in the sample, being a new record for this genus in the south African region.

\section{Material and methods}

\section{Sampling}

The moss sample was collected at the top of Table Mountain (approx. $33^{\circ} 57^{\prime} 43.9^{\prime \prime} \mathrm{S}, 18^{\circ} 24^{\prime} 38.0^{\prime \prime} \mathrm{E}$, $\approx 1000 \mathrm{~m}$ a.s.1.), in the Republic of South Africa, by Irina Nikolaeva, on January 10, 2008. Material was stored within paper envelopes at room temperature. Tardigrade specimens were extracted from rehydrated samples using the standard technique of washing them through two sieves (first with $\approx 1 \mathrm{~mm}$ mesh size and second with $35 \mu \mathrm{m}$ mesh size; Tumanov 2018a). The contents of the finer sieve were examined under a Leica M205C stereo microscope.

\section{Microscopy and imaging}

The tardigrades found in moss samples were fixed with acetic acid (a few drops of the concentrated acetic acid were added to the glass staining block containing tardigrade specimens in $\mathrm{ddH}_{2} \mathrm{O}$ ) and mounted on slides in Hoyer's medium. The mite specimen was directly mounted on a slide in Hoyer's medium without fixation. Light microscopy (LM): resulting permanent slides were examined under a Leica DM2500 microscope equipped with phase contrast $(\mathrm{PhC})$ and differential interference contrast (DIC). Photographs were made using a Nikon DS-Fi3 digital camera with NIS software.

For scanning electron microscopy (SEM), specimens were dehydrated in an ascending ethyl alcohol series $(10 \%, 20 \%, 30 \%, 50 \%, 70 \%, 96 \%)$ and acetone, critical-point dried in $\mathrm{CO}_{2}$, mounted on stubs and coated with gold. A Tescan MIRA3 LMU scanning electron microscope was used for observations (Centre for Molecular and Cell Technologies, St. Petersburg State University).

\section{Morphometrics}

The sample size for morphometrics was chosen following the recommendations of Stec et al. (2016). Structures were measured only if their orientations were suitable. Body length was measured from the anterior end of the body to the posterior end, excluding the hind legs. The bucco-pharyngeal tube 
was measured from the dorsal crests of the oral cavity armature (OCA) to the caudal end of the buccal tube, not including the buccal apophyses. Terminology for the structures within the bucco-pharyngeal apparatus and for the claws follows those of Pilato \& Binda (2010) and Michalczyk \& Kaczmarek (2003). Elements of the buccal apparatus, claws and eggs were measured according to Kaczmarek \& Michalczyk (2017). The macroplacoid length sequence is given according to Kaczmarek et al. (2014). All measurements are given in micrometres $(\mu \mathrm{m})$. The $p t$ index used is the percentage ratio between the length of a structure and the length of the buccal tube (Pilato 1981), and is presented here in italics. Morphometric data were handled using ver. 1.6 of the "Parachela" template, which is available from the Tardigrada Register (Michalczyk \& Kaczmarek 2013).

\section{Genotyping}

DNA was extracted from two individual animals using QuickExtract ${ }^{\mathrm{TM}}$ DNA Extraction Solution (Lucigen Corporation, USA) using the protocol kindly provided by Torbjørn Ekrem, Norwegian University of Science and Technology (see Supplementary file 1). Preserved exoskeletons were recovered, mounted on a microscope slide in Hoyer's medium and retained as the hologenophore (Pleijel et al. 2008).

Four genes were sequenced from one specimen: a small ribosome subunit (18S rRNA) gene, a large ribosome subunit (28S rRNA) gene, internal transcribed spacer (ITS-2), and the cytochrome oxidase subunit I (COI) gene. The primers and PCR programs used are provided in Table 1.

The PCR products were visualized in 1.5\% agarose gel stained with ethidium bromide. All amplicons were sequenced directly using the ABI PRISM Big Dye Terminator Cycle Sequencing Kit (Applied Biosystems, Foster City, CA, USA) using an ABI Prism 310 Genetic Analyzer in the Core Facilities Center 'Centre for Molecular and Cell Technologies' of St. Petersburg State University. Sequences were edited and assembled using ChromasPro software (Technelysium, USA). The COI sequences were translated to amino acids using the invertebrate mitochondrial code, implemented in MEGA7 (Kumar et al. 2016), in order to check for the presence of stop codons and therefore of pseudogenes.

All sequences of the genus Mesobiotus available in GenBank at the time of the analysis were downloaded, and those originating from published works with reliable attribution of the investigated taxa were selected (see Appendix 1). Sequences of the 28S gene published by Vecchi et al. (2016) (KT226079KT226087) and Guil et al. (2019) (MH079488, MH079489) were excluded from comparison as they do not overlap with the sequences obtained in this study. Sequences were aligned using the Muscle algorithm (Edgar 2004) with default settings, as implemented in SeaView ver. 4.0 (Gouy et al. 2010). Uncorrected pairwise distances were calculated using MEGA7 (Kumar et al. 2016) with gaps/ missing data treatment set to "complete deletion". All obtained sequences were deposited in GenBank (https://www.ncbi.nlm.nih.gov/genbank/).

\section{Mite identification}

A review paper (Bartsch 1989) was used for the preliminary identification of the mite specimen found. Other publications devoted to the descriptions of Lobohalacarus species and subspecies, and zoogeographical records for this genus (Harvey 1988; Bartsch 1995a, 1995b, 2008, 2018), were used for the final identification.

\section{Institutional acronyms}

Specimens from the following institutions and collections were examined (curator in parentheses).

$\mathrm{SPbU}=$ St. Petersburg University, Russia, Faculty of Biology, Department of Invertebrate Zoology (Denis Tumanov)

UNICT = Università degli Studi di Catania, Italy, Museum of the Department of Animal Biology 'Marcello La Greca', Binda and Pilato collection (Giovanni Pilato) 
Table 1. Primers and PCR programs used for amplification of the four DNA fragments sequenced in the study.

\begin{tabular}{|c|c|c|c|c|c|}
\hline $\begin{array}{l}\text { DNA } \\
\text { fragment }\end{array}$ & Primer name & $\begin{array}{c}\text { Primer } \\
\text { direction }\end{array}$ & Primer sequence $\left(5^{\prime}-3^{\prime}\right)$ & Primer source & PCR programme \\
\hline \multirow[t]{2}{*}{$\mathrm{COI}$} & LCO1490 & forward & GGTCAACAAATCATAAAGATATTGG & Folmer et al. 1994 & \multirow{2}{*}{ Michalczyk et al. 2012} \\
\hline & $\mathrm{HCO} 2198$ & reverse & TAAACTTCAGGGTGACCAAAAAATCA & Folmer et al. 1994 & \\
\hline \multirow[t]{3}{*}{ 18S rRNA } & 18S_Tar_Ff1 & forward & AGGCGAAACCGCGAATGGCTC & Stec et al. 2017 & \multirow{3}{*}{$\begin{array}{c}\text { Zeller (2010), } \\
\text { in Stec et al. } 2015\end{array}$} \\
\hline & 18S_Tar_Rr1 & reverse & GCCGCAGGCTCCACTCCTGG & Stec et al. 2017 & \\
\hline & $18 \mathrm{Sfw}$ & forward & CTTGTCTCAAAGATTAAGCCATGCA & Dabert et al. 2010 & \\
\hline \multirow[t]{2}{*}{ 28S rRNA } & 28S_Eutar_F & forward & ACCCGCTGAACTTAAGCATAT & Gąsiorek et al. 2018 & \multirow{2}{*}{ Mironov et al. 2012} \\
\hline & 28S_R0990 & reverse & CCTTGGTCCGTGTTTCAAGAC & Mironov et al. 2012 & \\
\hline \multirow[t]{2}{*}{ ITS-2 } & ITS2_Eutar_Ff & forward & CGTAACGTGAATTGCAGGAC & Stec et al. $2018 \mathrm{a}$ & \multirow{2}{*}{ Stec et al. 2018a } \\
\hline & ITS2_Eutar_Rr & reverse & TGATATGCTTAAGTTCAGCGG & Stec et al. 2018a & \\
\hline
\end{tabular}

\section{Results}

Phylum Tardigrada Doyère, 1840

Class Eutardigrada Richters, 1926

Superfamily Macrobiotoidea Thulin, 1928

Family Macrobiotidae Thulin, 1928

Genus Mesobiotus Vecchi, Cesari, Bertolani, Jönsson, Rebecchi \& Guidetti, 2016

Mesobiotus anastasiae sp. nov.

urn:1sid:zoobank.org:act:8651D164-4CBC-41DD-A5C4-FF9E584F8088

Figs 1-6, Tables 2-3

\section{Etymology}

I dedicate this new species to my daughter, Anastasia.

\section{Material examined}

\section{Holotype}

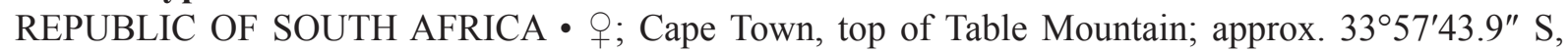
$18^{\circ} 24^{\prime} 38.0^{\prime \prime} \mathrm{E} ; \approx 1000 \mathrm{~m}$ a.s.1.; 10 Jan. 2008; I. Nikolaeva leg.; moss on soil, wet depression with a small temporary pond; SPbU 256(8).

\section{Paratypes}

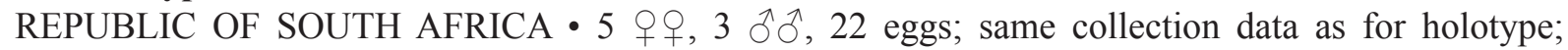
$\mathrm{SPbU} 256(1)$ to $256(6)$ and 256(9) to 256(18) 2 adults, 7 eggs; same collection data as for holotype; SEM stub; SPbU_Tar16.

\section{Comparative material}

PEOPLE'S REPUBLIC OF CHINA • 7 eggs, paratypes of Mesobiotus mauccii (Pilato, 1974); Canton; moss on tree bark; UNICT 2132.

\section{Morphological description}

Body elongated (Fig. 1A-B) (morphometrics in Table 2, raw morphometric data are provided in Supplementary file 2). Fresh specimens uncolored or whitish with slightly greenish gut content, 
transparent after fixation in Hoyer's medium. Four specimens with eyes (Fig. 1A), usually welldiscernible after slide mounting, three specimens without eyes; in two specimens processed for DNA extraction the presence or absence of eyes was not registered. Dorsal cuticle in LM with poorly visible network-like pattern (Fig. 2A). SEM investigation revealed presence of flat tubercles all over the body surface (Fig. 2B-C). Additionally, the body surface is covered with regularly distributed small granules (invisible in LM; Fig. 2B). In the dorso-lateral position, above the bases of the hind legs, zones of concentrated granules are present (Fig. 2C). All legs with granulated areas. Legs I-III with small granulated areas on the external surfaces, near the claw bases (Fig. 4A), invisible or extremely poorly visible in LM (Fig. 4D, black arrowhead), the internal leg surfaces without granulation, with indistinct pulvinus (Fig. 4B, white asterisk). Legs IV with better-developed granulation dorsally (Fig. 2D) and around the claw bases (Fig. 4G).

Buccal-pharyngeal apparatus of Macrobiotus type (Fig. 3A) with ventral lamina and ten peribuccal lamellae. Oral cavity armature (OCA) of modified krynauwi type (according to Kaczmarek et al. 2020) with three bands of teeth visible in LM. Evident first (anterior) band consists of a single uneven line of relatively large and slightly longitudinally elongated teeth (Fig. 3F, J-K, O, black arrowheads). Second band consists of a wide zone of small dot-like teeth (Fig. 3G, I, L, N), teeth of the anterior-most and
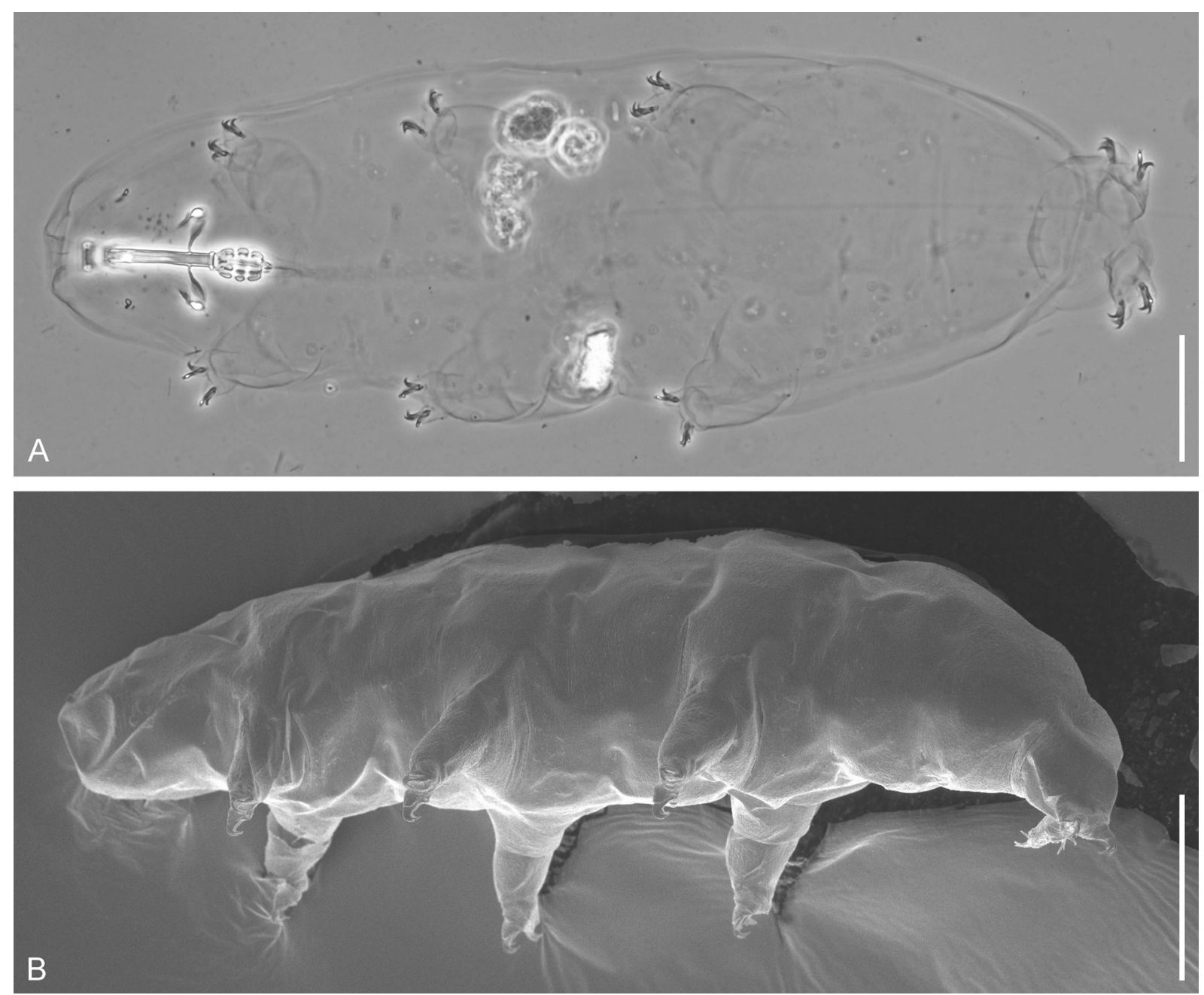

Fig. 1. Mesobiotus anastasiae sp. nov., total view. A. Holotype, $q$ (SPbU 256(8)). Dorso-ventral view, PhC. B. Paratype (SPbU_Tar16). Lateral view in SEM. Scale bars $=50 \mu \mathrm{m}$. 
Table 2. Summary of morphometric data for Mesobiotus anastasiae sp. nov. Measurements are given in $\mu \mathrm{m}, p t$ values in \% (the $p t$ index is the percentage ratio between the length of a structure and the length of the buccal tube).

\begin{tabular}{|c|c|c|c|c|c|c|c|c|c|}
\hline \multirow{2}{*}{ CHARACTER } & \multirow{2}{*}{$\mathbf{N}$} & \multicolumn{2}{|c|}{ RANGE } & \multicolumn{2}{|c|}{ MEAN } & \multicolumn{2}{|c|}{ SD } & \multicolumn{2}{|c|}{ Holotype } \\
\hline & & $\mu \mathrm{m}$ & $p t$ & $\mu \mathrm{m}$ & $p t$ & $\mu \mathbf{m}$ & $p t$ & $\mu \mathbf{m}$ & $p t$ \\
\hline Body length & 7 & $284-426$ & $809-1002$ & 366 & 909 & 44 & 83 & 426 & 1002 \\
\hline \multicolumn{10}{|l|}{ Buccopharyngeal tube } \\
\hline Buccal tube length & 9 & $35.1-45.5$ & - & 40.8 & - & 3.5 & - & 42.6 & - \\
\hline Stylet support insertion point & 9 & $26.5-35.8$ & $75.3-78.7$ & 31.5 & 77.1 & 3.1 & 1.2 & 33.1 & 77.8 \\
\hline Buccal tube external width & 7 & $4.1-6.0$ & $11.3-13.1$ & 5.1 & 12.2 & 0.6 & 0.6 & 5.4 & 12.7 \\
\hline Buccal tube internal width & 7 & $2.8-4.0$ & $7.6-8.8$ & 3.4 & 8.2 & 0.4 & 0.4 & 3.6 & 8.5 \\
\hline Ventral lamina length & 9 & $21.9-30.7$ & $62.2-67.4$ & 26.2 & 64.1 & 2.7 & 1.7 & 27.1 & 63.8 \\
\hline \multicolumn{10}{|l|}{ Placoid lengths } \\
\hline Macroplacoid 1 & 9 & $3.7-6.1$ & $10.0-13.4$ & 4.8 & 11.7 & 0.9 & 1.3 & 5.2 & 12.2 \\
\hline Macroplacoid 2 & 9 & $2.8-4.4$ & $8.0-10.3$ & 3.6 & 8.9 & 0.5 & 0.7 & 4.4 & 10.3 \\
\hline Macroplacoid 3 & 9 & $3.2-6.4$ & $9.1-14.6$ & 4.7 & 11.4 & 1.1 & 1.9 & 5.4 & 12.6 \\
\hline Microplacoid & 9 & $2.0-3.3$ & $5.3-7.7$ & 2.6 & 6.3 & 0.5 & 0.9 & 3.3 & 7.7 \\
\hline Macroplacoid row & 9 & $11.7-18.3$ & $33.0-41.9$ & 15.1 & 36.8 & 2.5 & 3.2 & 16.6 & 38.9 \\
\hline Placoid row & 9 & $13.9-21.5$ & $39.0-49.0$ & 18.2 & 44.3 & 2.9 & 3.9 & 19.7 & 46.2 \\
\hline \multicolumn{10}{|l|}{ Claw 1 lengths } \\
\hline External primary branch & 5 & $7.6-10.8$ & $21.6-24.5$ & 9.4 & 23.1 & 1.2 & 1.2 & 9.9 & 23.4 \\
\hline External secondary branch & 5 & $5.9-8.0$ & $16.8-19.1$ & 7.2 & 17.7 & 0.8 & 0.9 & 7.4 & 17.5 \\
\hline Internal primary branch & 7 & $7.3-10.5$ & $20.8-23.8$ & 9.0 & 22.2 & 1.0 & 1.0 & 9.4 & 22.0 \\
\hline Internal secondary branch & 7 & $5.9-8.3$ & $16.1-18.2$ & 7.0 & 17.3 & 0.8 & 0.9 & 6.8 & 16.1 \\
\hline \multicolumn{10}{|l|}{ Claw 2 lengths } \\
\hline External primary branch & 6 & $8.0-10.8$ & $22.4-24.7$ & 9.4 & 23.5 & 1.0 & 0.9 & 10.2 & 23.9 \\
\hline External secondary branch & 6 & $6.6-8.4$ & $17.2-19.3$ & 7.4 & 18.5 & 0.7 & 0.7 & 8.0 & 18.9 \\
\hline Internal primary branch & 6 & $7.4-10.1$ & $21.0-23.8$ & 9.0 & 22.6 & 1.1 & 1.1 & 10.1 & 23.8 \\
\hline Internal secondary branch & 6 & $6.0-7.7$ & $16.2-19.4$ & 7.0 & 17.5 & 0.6 & 1.1 & 7.7 & 18.1 \\
\hline \multicolumn{10}{|l|}{ Claw 3 lengths } \\
\hline External primary branch & 6 & $7.8-10.9$ & $22.0-25.1$ & 9.5 & 23.5 & 1.1 & 1.3 & 10.3 & 24.1 \\
\hline External secondary branch & 6 & $6.1-8.8$ & $17.2-20.1$ & 7.5 & 18.4 & 0.9 & 1.1 & 8.0 & 18.7 \\
\hline Internal primary branch & 7 & $7.1-10.7$ & $20.2-24.6$ & 9.4 & 22.8 & 1.3 & 1.4 & 10.1 & 23.8 \\
\hline Internal secondary branch & 7 & $5.8-8.2$ & $16.4-18.4$ & 7.2 & 17.4 & 0.9 & 0.9 & 7.8 & 18.4 \\
\hline \multicolumn{10}{|l|}{ Claw 4 lengths } \\
\hline Anterior primary branch & 6 & $9.8-12.3$ & $24.7-28.2$ & 11.1 & 26.4 & 1.0 & 1.2 & 11.4 & 26.9 \\
\hline Anterior secondary branch & 6 & $7.0-8.6$ & $17.0-20.3$ & 7.9 & 18.8 & 0.6 & 1.1 & 8.6 & 20.3 \\
\hline Posterior primary branch & 5 & $11.7-12.9$ & $27.2-30.2$ & 12.3 & 28.6 & 0.6 & 1.2 & 12.9 & 30.2 \\
\hline Posterior secondary branch & 5 & $8.0-9.4$ & $18.7-20.6$ & 8.6 & 19.9 & 0.6 & 0.7 & 8.7 & 20.4 \\
\hline
\end{tabular}

(rarely) posterior-most rows of the second band are slightly larger than others, sometimes teeth of the anterior-most row are very slightly longitudinally elongated. Third band comprises three dorsal and three ventral transverse ridges (Fig. 3H, J, M, O). Medio-ventral ridge is usually more or less clearly divided into two separate parts (Fig. 3J, O). Pharyngeal bulb with apophyses, three macroplacoids and a large microplacoid (Fig. 3A). Macroplacoid length sequence is $2<3=1$. First macroplacoid is anteriorly 
narrowed, third macroplacoid without distinct subterminal constriction, but with strong terminal protrusion, directed towards pharynx lumen (Fig. 3B-E, black arrowheads).

Claws of Mesobiotus type with minute stalk, distinct distal part of the basal portion, short common tract and developed internal septum, defining a distal part. Primary and secondary branches diverge at a point near half the claw height, main branches with long accessory points, which at a large distance from the main claw (Fig. 4C, E-F, H). Claws of fourth pair of legs slightly longer than claws of first three pairs of legs (Fig. 4H). All claws with smooth lunules (Fig. 4C, E-F, H). Anterior (internal) and posterior (external) claws of legs IV are similar in shape, with equally sized lunules. Poorly developed bar-like cuticular thickenings are present below claw bases of the first three pairs of legs (Fig. 4C, black arrowhead). Claws of legs IV are connected with a wide horseshoe-like structure (Fig. 4F, black arrowhead).
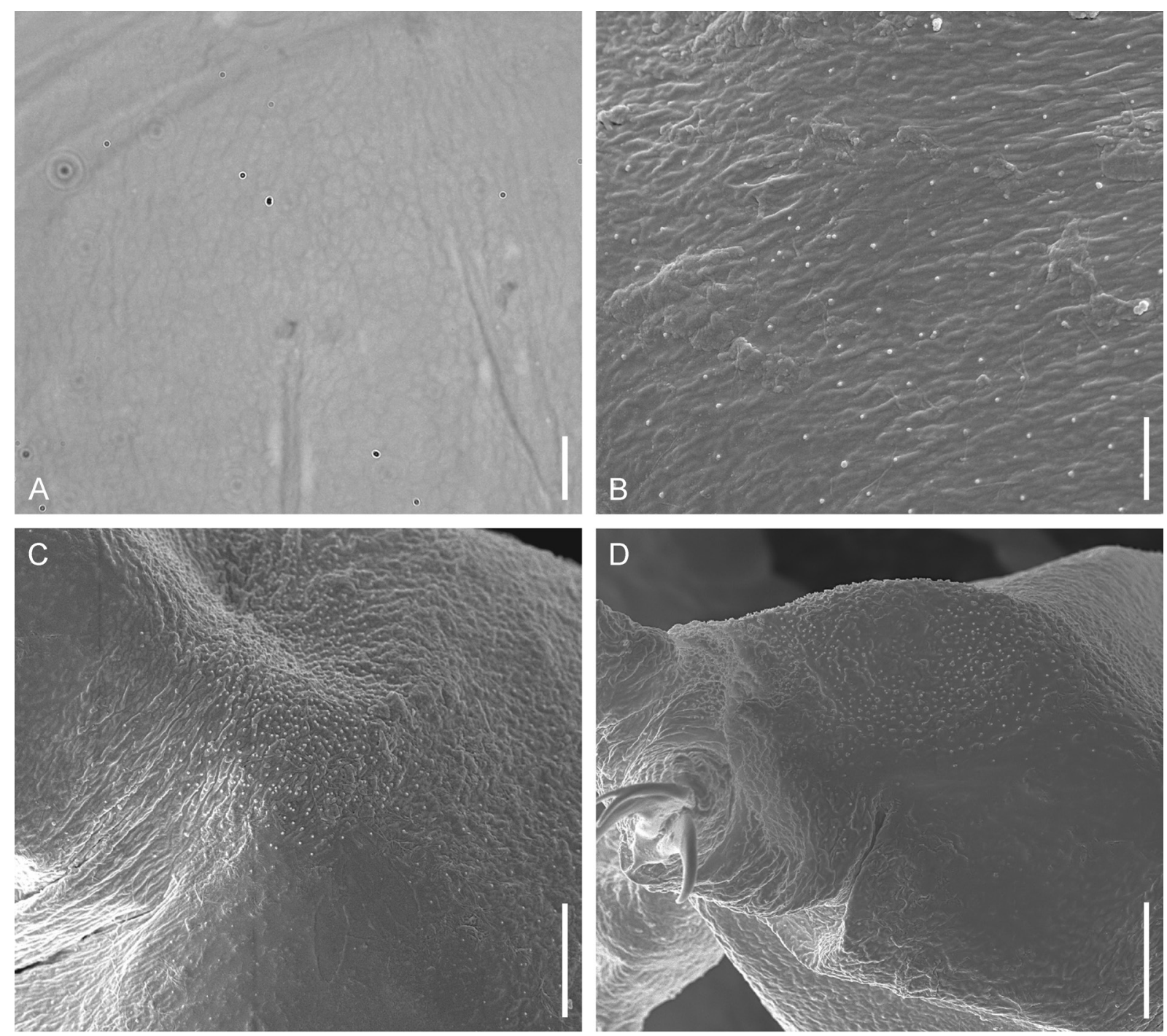

Fig. 2. Mesobiotus anastasiae sp. nov., cuticular sculpture. A. Paratype (SPbU 256(18)). Sculpture of the dorsal body surface, PhC. B-D. Paratype (SPbU_Tar16). B. High magnification of the sculpture of the dorsal body surface, SEM. C. Dorso-lateral zone of concentrated cuticular dots, SEM. D. Dot-like sculpture on the dorsal side of hind legs, SEM. Scale bars A, C, D $=5 \mu \mathrm{m} ; \mathrm{B}=2 \mu \mathrm{m}$. 

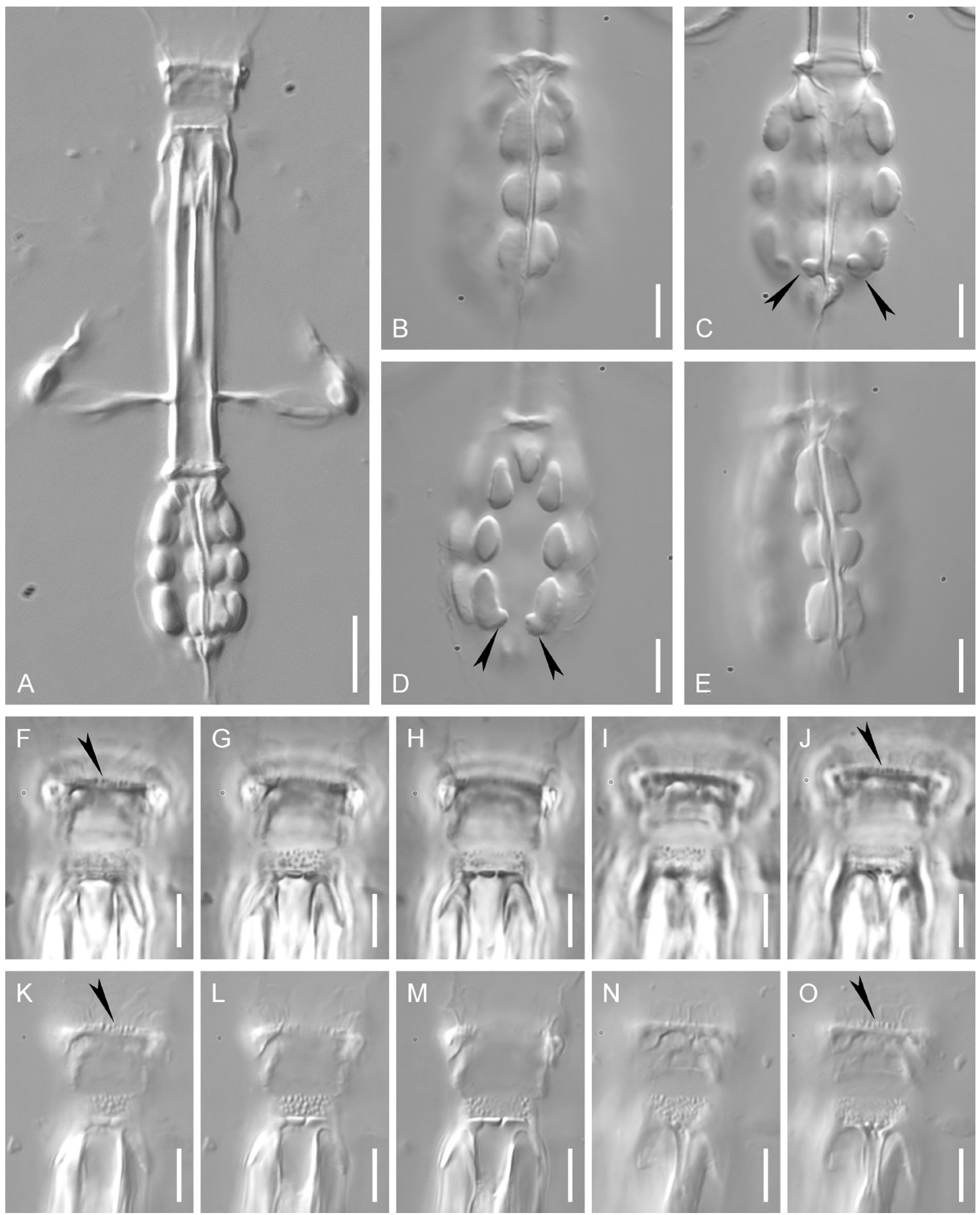

Fig. 3. Mesobiotus anastasiae sp. nov., bucco-pharyngeal apparatus. A, E-O. Paratype, $\varnothing$ (SPbU 256(9)). B-D. Holotype, $\circ$ (SPbU 256(8)). A. Total dorso-ventral view of the bucco-pharyngeal apparatus, DIC. B. Ventral row of macroplacoids, focused on their outer surface, DIC. C. Ventral row of macroplacoids, focal plane shifted deeper into the parynx, black arrowheads indicate appendices of the third macroplacoid bent inward, DIC. D. Lateral rows of macroplacoids, black arrowheads indicate appendices of the third macroplacoid bent inward, DIC. E. Ventral row of macroplacoids, focused on their outer surface; note the absence of the preterminal constriction of the third macroplacoid, DIC. F-O. Oral cavity armature, dorsal $(\mathrm{F}-\mathrm{H}, \mathrm{K}-\mathrm{M})$ and ventral view $(\mathrm{I}-\mathrm{J}, \mathrm{N}-\mathrm{O})$, black arrowheads indicate teeth of the first band, $\mathrm{F}-\mathrm{J}=$ PhC, $\mathrm{K}-\mathrm{O}=$ DIC. Scale bars: $\mathrm{A}=10 \mu \mathrm{m} ; \mathrm{B}-\mathrm{O}=5 \mu \mathrm{m}$. 

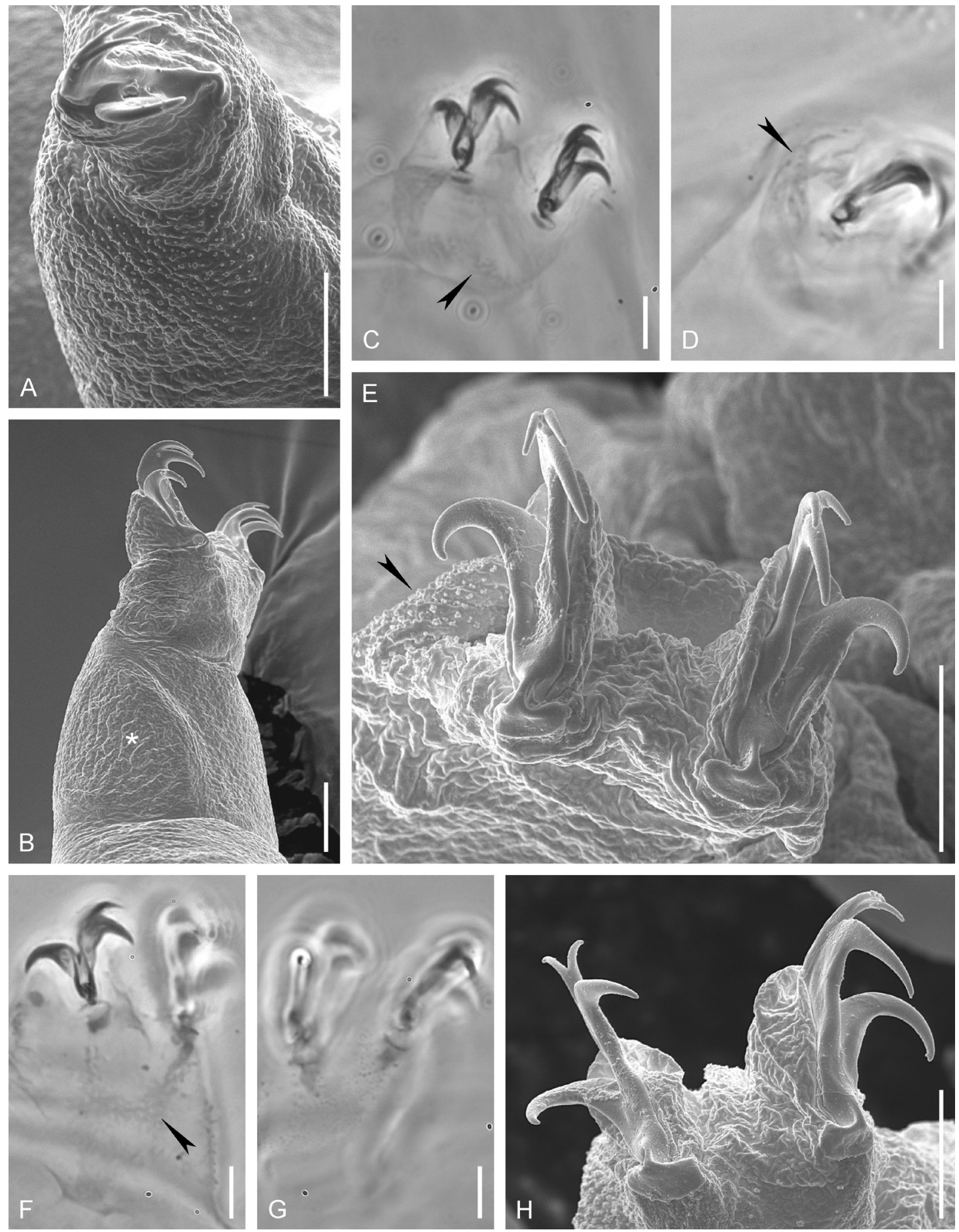

Fig. 4. Mesobiotus anastasiae sp. nov., paratype (SPbU_Tar16). Legs. A. External surface of leg III with developed dot-like sculpture, SEM. B. Internal surface of leg II without dot-like sculpture, white asterisk - pulvinus on the inner side of the leg, SEM. C. Claws of leg I, black arrowhead indicates barlike cuticular thickening (holotype), PhC. D. Leg II, black arrowhead indicates dot-like sculpture on the external surface (SPbU 256(1), paratype), PhC. E. Claws of leg II, black arrowhead indicates dotlike sculpture on the external surface of the leg, SEM. F. Claws of leg IV, black arrowhead indicates horseshoe-like structure (SPbU 256(13), paratype), PhC. G. Leg IV, dot-like sculpture on the ventral surface (holotype), PhC. H. Claws of leg IV, SEM. Scale bars $=5 \mu \mathrm{m}$. 

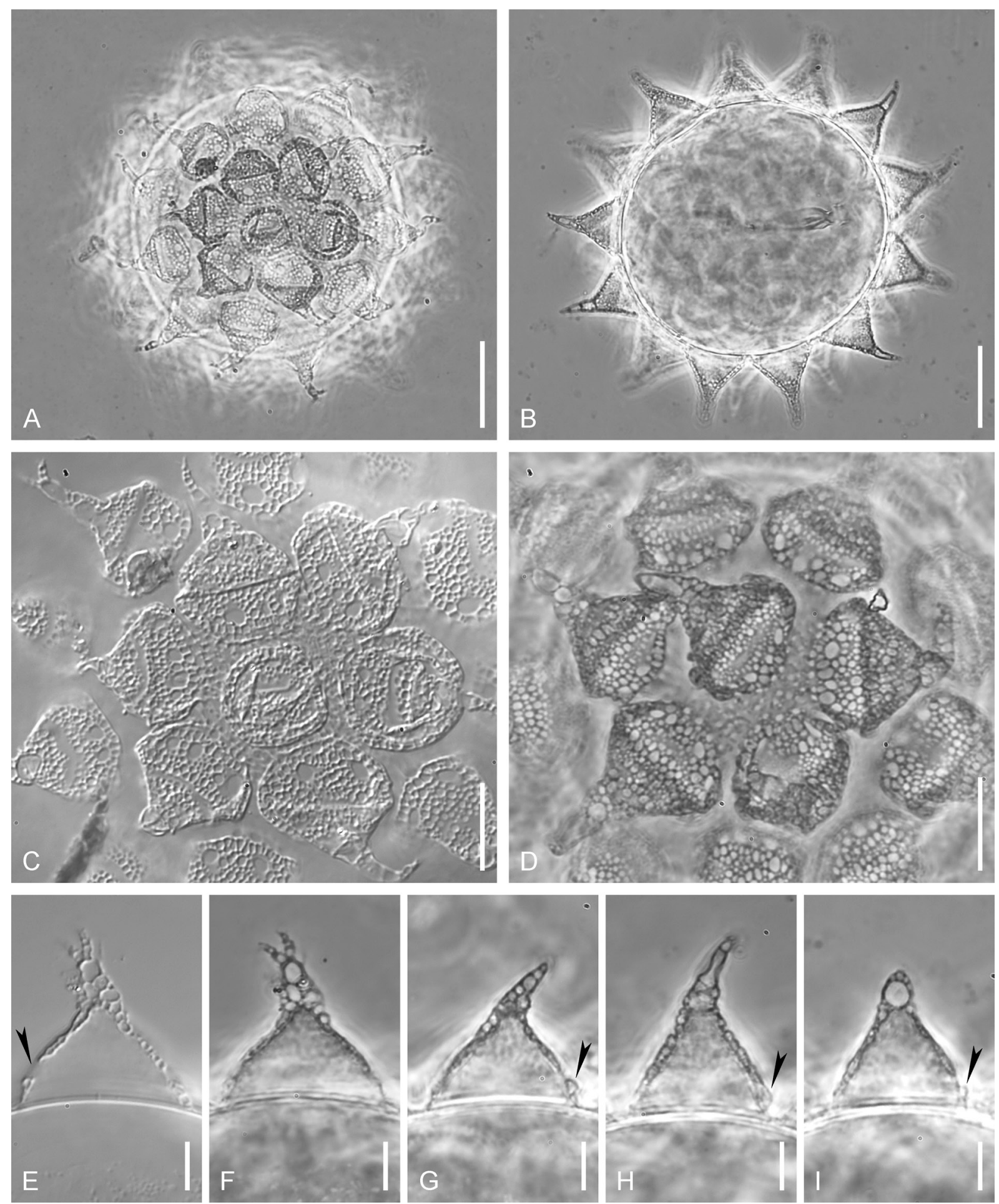

Fig. 5. Mesobiotus anastasiae sp. nov., eggs. A-F. Paratype (SPbU 256(15)). G-I. Paratype (SPbU 256(4)). A. Total view of the egg surface, PhC. B. Total view of the optical section of the embryonated egg, PhC. C-D. Details of the egg surface, DIC, PhC. E. Optical section of the egg process, black arrowhead indicates pore, DIC. F-I. Optical sections of different egg processes, black arrowheads indicate collar, PhC. Scale bars: A-B $=20 \mu \mathrm{m} ; \mathrm{C}-\mathrm{D}=10 \mu \mathrm{m} ; \mathrm{E}-\mathrm{I}=5 \mu \mathrm{m}$. 

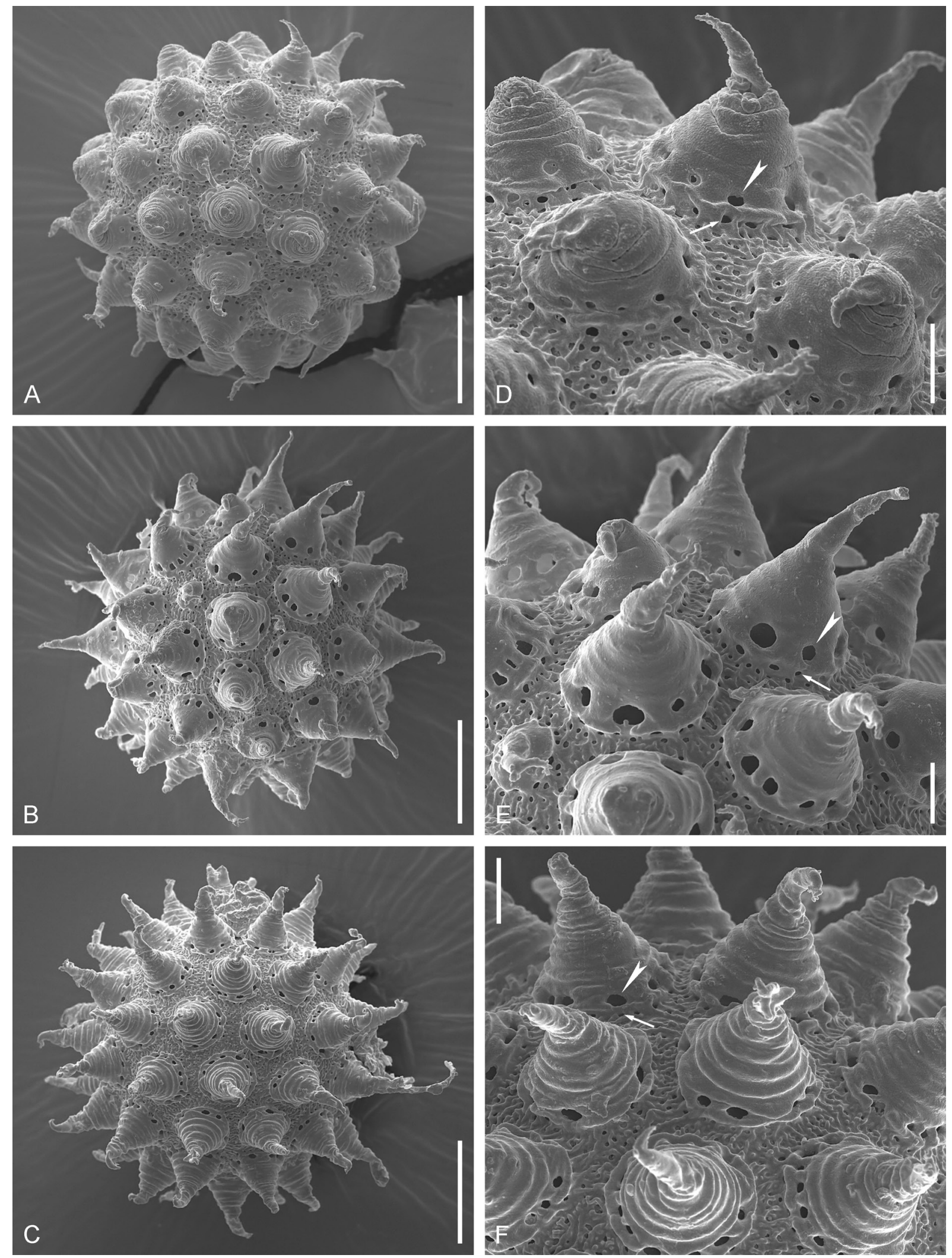

Fig. 6. Mesobiotus anastasiae sp. nov., paratype (SPbU_Tar16). Eggs. A-C. Total view of the egg, SEM. D-F. Details of the egg surface, white arrowheads indicate pores above the collar, white arrows indicate pores below the collar, SEM. Scale bars: A-C $=20 \mu \mathrm{m}$; D-F $=5 \mu \mathrm{m}$. 
Table 3. Measurements (in $\mu \mathrm{m}$ ) of selected morphological structures of eggs of Mesobiotus anastasiae sp. nov. Abbreviations: $\mathrm{N}=$ number of eggs/structures measured, range refers to the smallest and the largest structure among all measured specimens; $\mathrm{SD}=$ standard deviation.

\begin{tabular}{lcccc}
\hline CHARACTER & N & RANGE & MEAN & SD \\
\hline Egg bare diameter & 13 & $61.7-74.7$ & 66.7 & 4.0 \\
Egg full diameter & 13 & $84.6-108.5$ & 95.9 & 7.1 \\
Process height & 39 & $14.6-21.3$ & 17.7 & 1.8 \\
Process base width & 39 & $11.8-18.6$ & 15.5 & 1.6 \\
Process base/height ratio & 39 & $63 \%-117 \%$ & $88 \%$ & $9 \%$ \\
Inter-process distance & 39 & $0.0-3.8$ & 1.3 & 0.9 \\
Number of processes on egg circumference & 13 & $12-15$ & 13.4 & 0.9 \\
\hline
\end{tabular}

Eggs spherical, white, ornamented and laid freely (Figs 5A-B, 6A-C; morphometrics in Table 3). Chorion with conical processes that can be attributed to the "sharp wide cones with collars" and "reticular design with "bubbles"”" morphotypes (according to Kaczmarek et al. 2020). Egg processes with wide bases and thinned and flexible apices (Figs 5C-I, 6D-F). Basal parts of the processes with bilayered walls, with a net of trabecular structures between the internal and external layers, forming irregular rounded meshes of different size, so the processes seem to be reticulated in LM (Fig. 6C-I). Apical parts of the processes with bubble-like internal structure (Fig. 5E-I), often branching (Figs 5E-F, 6E-F). The SEM observations revealed circular wrinkles on the outer surface of the processes (Fig. 6D-F). Basal parts of the processes with well-developed collar elevated above the egg surface (Figs 5G-I, black arrowheads; 6D-F). Large pores (1-3 $\mu \mathrm{m}$ in diameter), visible in LM and in SEM, are present on the surface of all processes, near the collar, in two rows: one row of larger pores above the collar and second row of smaller pores below the collar (Figs 5C-E, black arrowhead; 6D-F). Process bases are smooth, without a crown of granules or teeth. Egg surface between the processes without areolation, with a system of
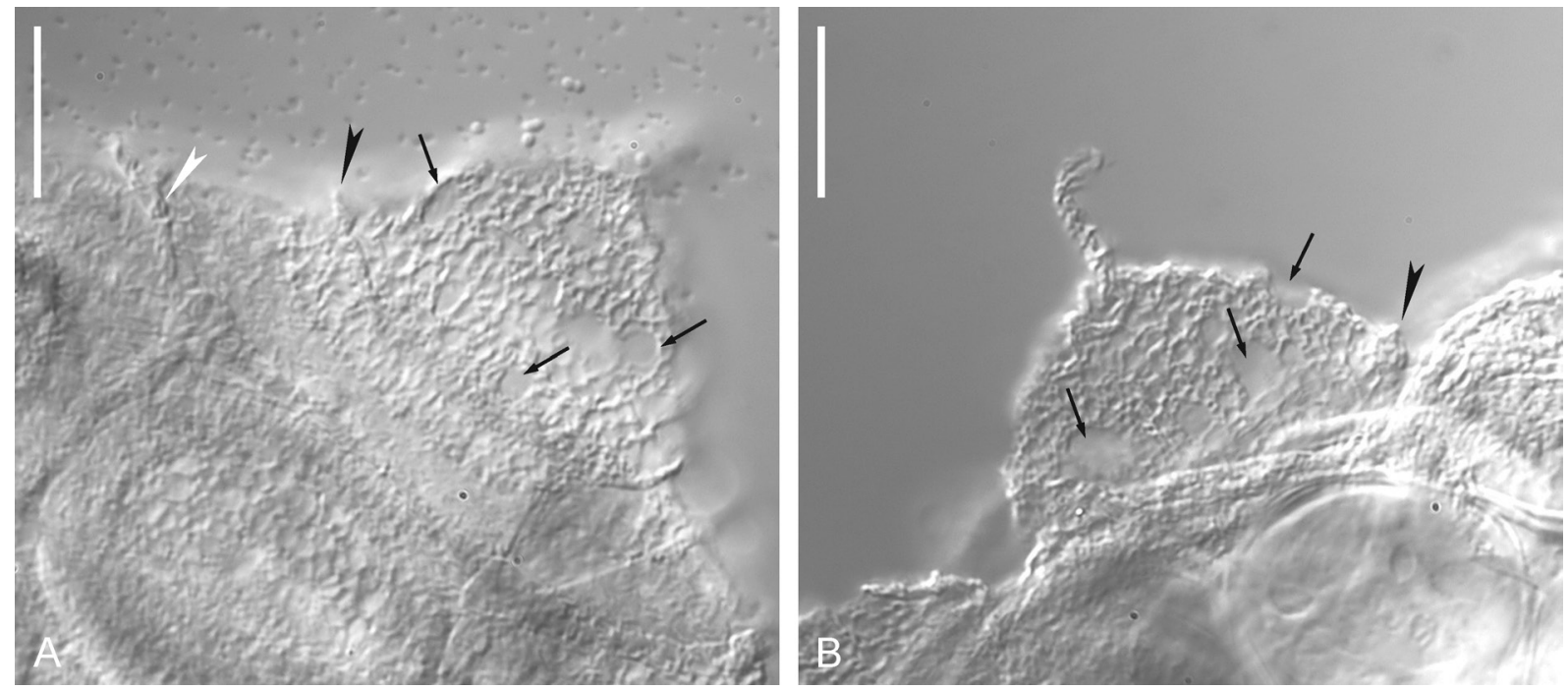

Fig, 7. Mesobiotus manccii (Pilato, 1974). Paratype egg (UNICT 2132). A-B. Egg processes, white arrowhead indicates polygonate mesh-like pattern, black arrowheads indicate the collar, black arrows indicate pores, DIC. Scale bars: $10 \mu \mathrm{m}$. 
irregularly distributed ridges and small pores between them (Fig. 6D-F). In some eggs underdeveloped small processes are present among normal processes (Fig. 6B, E).

\section{Reproduction}

The new species is dioecious. Adult males were identified by having testis filled with spermatozoa, visible under $\mathrm{PhC}$ on mounted slides. Males of $M$. anastasiae sp. nov. exhibit no secondary sexual dimorphism.

\section{DNA sequences}

Sequences of good quality for the four aforementioned molecular markers were obtained from one specimen (voucher slide SpbU 256(11)):

COI sequence (GenBank: MT904513), 658 bp long;

18S rRNA sequence (GenBank: MT903468), 1030 bp long;

28S rRNA sequence (GenBank: MT903612), 740 bp long;

ITS-2 sequence (GenBank: MT903470), 419 bp long.

Phylum Arthropoda von Siebold, 1848

Subphylum Chelicerata Heymons, 1901

Class Arachnida Lamarck, 1801

Superorder Acariformes Zakhvatkin, 1952

Family Halacaridae Murray, 1877

Lobohalacarus cf. weberi (Romijn \& Viets, 1924)

Fig. 8

\section{Material examined}

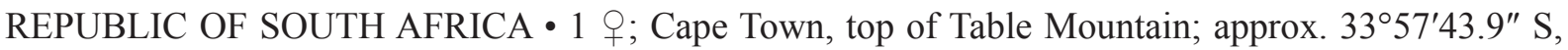
$18^{\circ} 24^{\prime} 38.0^{\prime \prime} \mathrm{E} ; \approx 1000 \mathrm{~m}$ a.s.1.; 10 Jan. 2008; I. Nikolaeva leg.; moss on soil, wet depression with a small temporary pond; SPbU 256(20).

During sample processing, a single mite specimen from the family Halacaridae (Chelicerata, Trombidiformes) was found (Fig. 8A). In having an undivided ventral shield (Fig. 8B) and developed frontal spine (Fig. 8C) this specimen undoubtedly belongs to the Lobohalacarus weberi complex of species, and is the first record of this genus from southern Africa (Bartsch 2018). Apart from its nominative variable species Lobohalacarus weberi (Romijn \& Viets, 1924), this complex includes several similar species and subspecies with unclear taxonomic status (Bartsch 1995a, 2018). The studied specimen is similar to Lobohalacarus weberi tristanensis Bartsch, 1995 (known from Tristan da Cunha Islands only) by having genu I with two ventral spines (Fig. 8A, black arrows) and genital sclerites with two pairs of genital acetabula (Fig. 8D, white arrowheads), but differs from this form by having five pairs of perigenital setae (Fig. 8B, white arrowheads).

\section{Discussion}

\section{Phenotypic differential diagnosis of Mesobiotus anastasiae sp. nov.}

\section{Adult animals}

Within the genus Mesobiotus, only two species have OCA of the krynauwi type - without the row of the longitudinally elongated teeth in the second band and with a developed first row of teeth: M. krynauwi (Dastych \& Harris, 1995) and M. tehuelchensis (Rossi, Claps \& Ardohain, 2009). 

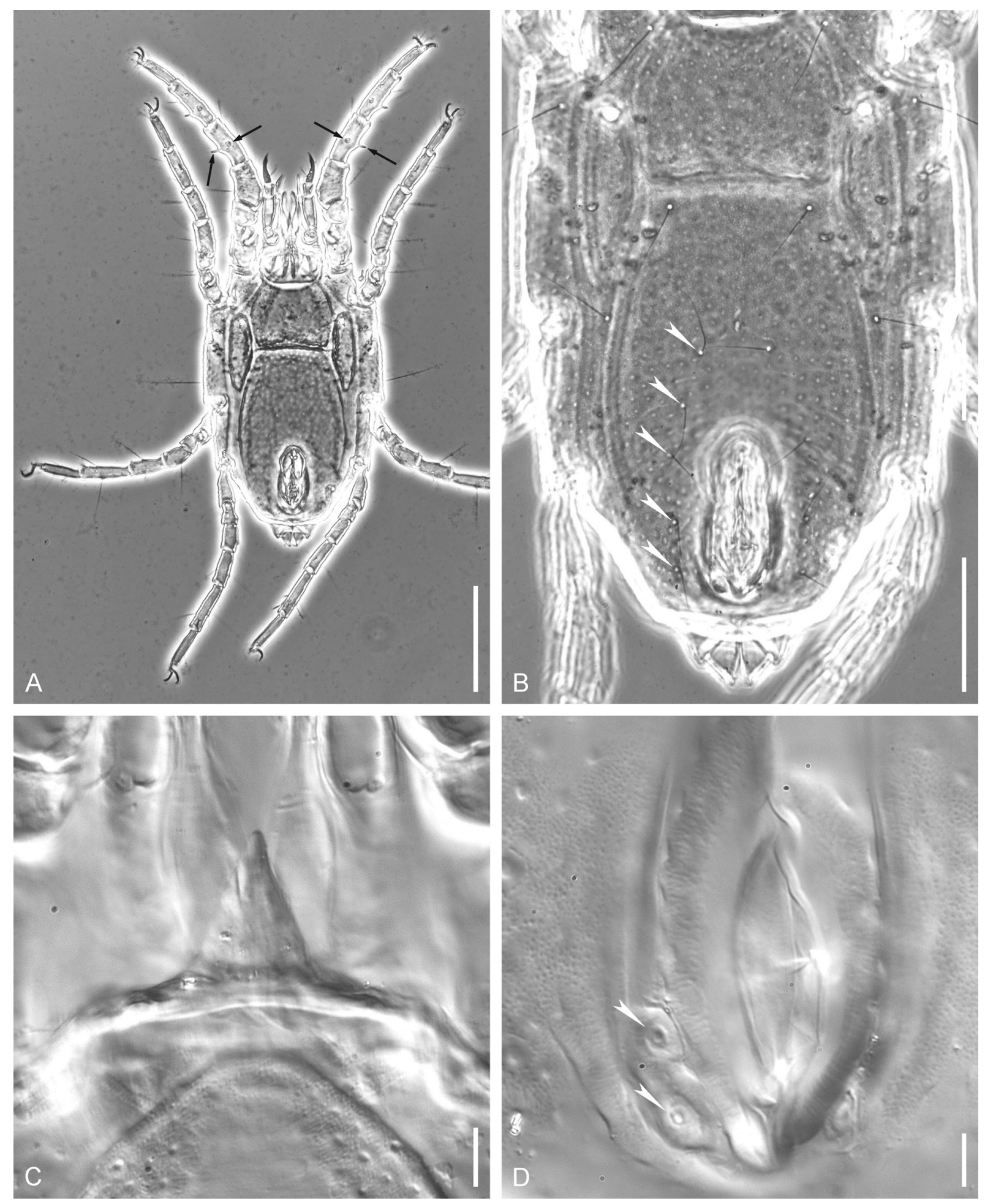

Fig. 8. Lobohalacarus cf. weberi, + (SPbU 256(20)). A. Total view, black arrows indicate spines on genua I, PhC. B. Ventral shield, white arrowheads indicate bases of perigenital setae, PhC. C. Frontal spine, DIC. D. Genital opening, white arrowheads indicate genital acetabula, DIC. Scale bars: A = $100 \mu \mathrm{m} ; \mathrm{B}=50 \mu \mathrm{m} ; \mathrm{C}=10 \mu \mathrm{m} ; \mathrm{D}=5 \mu \mathrm{m}$. 
Mesobiotus anastasiae sp. nov. differs from M. krynauwi (Dastych \& Harris, 1995) (known from several locations in Antarctica only, Dastych \& Harris 1995) by having cuticle with thin reticulate pattern visible in $\mathrm{PhC}$ (smooth cuticle with small pores in M. krynauwi), by having the first band of teeth of OCA consisting of a single line of elongated teeth (several lines of minute dot-like teeth in M. krynauwi), by having lunules of the hind legs without teeth (usually with sharp teeth in M. krynauwi), by having eggs with a smaller bare egg diameter $(61.7-74.7 \mu \mathrm{m}$ in $M$. anastasiae sp. nov. vs $98-115 \mu \mathrm{m}$ in $M$. krynauwi), larger egg processes (processes height 14.6-21.3 $\mu \mathrm{m}$ in M. anastasiae sp. nov. vs 9-14 $\mu \mathrm{m}$ in M. krynauwi) with large pores and collar (absent in M. krynauwi), and by having the egg surface between processes with ridges and pores (smooth in M. krynauwi).

Mesobiotus anastasiae sp. nov. differs from M. tehuelchensis (Rossi, Claps \& Ardohain, 2009) (known only from the type locality in Agentina, Rossi et al. 2009) by having cuticle with thin reticulate pattern visible in $\mathrm{PhC}$ (smooth cuticle in M. tehuelchensis), by having the first band of teeth of OCA consisting of a single line of elongated teeth (several lines of minute dot-like teeth in M. tehuelchensis), by having a thinner buccal tube (external buccal tube width is $4.1-6.0 \mu \mathrm{m}$ vs $9.9-14.9 \mu \mathrm{m}$ in M. tehuelchensis), by having eggs with a smaller bare egg diameter $(61.7-74.7 \mu \mathrm{m}$ in $M$. anastasiae sp. nov. vs $77 \mu \mathrm{m}$ in M. tehuelchensis), and smaller egg processes (processes height $14.6-21.3 \mu \mathrm{m}$ in M. anastasiae sp. nov. vs $\approx 50 \mu \mathrm{m}$ in M. tehuelchensis) with large pores and a collar (absent in M. tehuelchensis).

\section{Eggs}

Based on the morphology of the processes, eggs of $M$. anastasiae sp. nov. should be attributed to the "sharp wide cones with collar" morphotype (Kaczmarek et al. 2020). Within the genus Mesobiotus only two species have this type of egg processes: M. joenssoni Guidetti et al., 2019 and M. mauccii (Pilato, 1974) (the former species' eggs were erroneously attributed to the "sharp narrow cones" morphotype in Kaczmarek et al. (2020)). In all three species, the conical processes have a wide base with a developed collar (or "circular thickness" (Guidetti et al. 2019)), situated on the process wall above the egg surface. Additionally, the egg processes of all three species bear large pores on their side walls.

Mesobiotus anastasiae sp. nov. differs from M. joenssoni (known only from the type locality on Elba Island, Italy, Guidetti et al. 2019) by having cuticle with thin reticulate pattern visible in $\mathrm{PhC}$ (cuticle with large (visible in LM) granules in the caudal region of the dorsal side in M. joenssoni), by having OCA without elongated teeth in the second band (developed in M. joenssoni), by having the first band of teeth of OCA consisting of a single line of elongated teeth (several lines of minute dot-like teeth in M. joenssoni), by having eggs with smaller egg processes (processes height $14.6-21.3 \mu \mathrm{m}$ in M. anastasiae sp. nov. vs $27-36 \mu \mathrm{m}$ in $M$. joenssoni) with larger and more numerous pores above the collar, and with a second line of pores below the collar (absent in M. joenssoni).

Mesobiotus anastasiae sp. nov. differs from M. mauccii (known from several Asian locations: China (Pilato 1974; Beasley \& Miller 2007, 2012), South Andaman Island (Maucci \& Durante Pasa 1980), Japan (Utsugi 1988; Abe \& Takeda 2000, 2005)) by having cuticle with thin reticulate pattern visible in PhC (cuticle smooth in M. mauccii), by having OCA without elongated teeth in the second band (developed in M. mauccii), by having the first band of teeth of OCA consisting of a single line of elongated teeth (several lines of minute dot-like teeth in $M$. mauccii), by having a thinner buccal tube (external buccal tube width is $4.1-6.0 \mu \mathrm{m}$ vs ca $11 \mu \mathrm{m}$ in $M$. mauccii type material), by having egg processes with numerous pores arranged in lines above and below the collar (rare single pores are distributed all over the process surface in $M$. mauccii), and in lacking ridges on the egg surface between the processes, forming a mesh-like pattern with polygonate cells circling each process (Fig. 7A-B). 


\section{Genotypic differential diagnosis of Mesobiotus anastasiae sp. nov.}

The ranges of uncorrected genetic $p$-distances between the studied population of Mesobiotus anastasiae sp. nov. and other species of the genus Mesobiotus, for which sequences are available from GenBank (see Appendix 1), are as follows:

COI: $19.15 \%-26.60 \%$ (mean $21.66 \%$ ), with the most similar being $M$. gr. furciger from Norway (MH195153, Kaczmarek et al. 2018), and the least similar being M. furciger (Murray, 1907) from Antarctica (JX865308, Czechowski et al. 2012).

18S rRNA: $1.29 \%-6.01 \%$ (mean 3.47\%), with the most similar being M. occultatus Kaczmarek, Zawierucha, Buda, Stec, Gawlak, Michalczyk \& Roszkowska, 2018 from Svalbard (MH197147, Kaczmarek et al. 2018), and the least similar being M. dilimanensis from the Philippines (MN257048, Itang et al. 2020).

28S rRNA: $4.56 \%-12.11 \%$ (mean $7.70 \%$ ), with the most similar being M. harmsworthi (Murray, 1907) from Svalbard (MH197264, Kaczmarek et al. 2018), and the least similar being M. dilimanensis (MN257049, Itang et al. 2020).

ITS-2: $13.03 \%-29.83 \%$ (mean 20.47\%), with the most similar being M. philippinicus Mapalo, Stec, Mirano-Bascos \& Michalczyk, 2016 from the Philippines (KX129795, Mapalo et al. 2016), and the least similar being M. dilimanensis (MN257050, Itang et al. 2020).

Full matrices with $p$-distances are provided in Supplementary file 3.

\section{Ecological notes}

The location where the investigated moss sample was taken was characterized by the collector as a wet depression with a small temporary pond. But the genus Lobohalacarus, which was also found in the sample, is known to inhabit constant water bodies, primarily subterranean waters and areas where hypogean waters meet the surface (Bartsch 1995a), so the presence of this mite in the sample likely indicates that the type location for Mesobiotus anastasiae sp. nov. can be a permanently wet moss cushion. The presence of the single mite specimen can also be the result of an accidental introduction, but this seems to be less probable, because of the absence of permanent bodies of water in close proximity to the sampling site (I. Nikolaeva pers. com.) and the limited abilities of Halacaridae to tolerate desiccation.

\section{Acknowledgements}

I would like to thank Irina Nikolaeva (Zoological Institute, Russian Academy of Sciences, St. Petersburg) for collecting the material studied here. I thank Professor Giovanni Pilato and Professor Oscar Lisi (University of Catania, Italy) for giving me the opportunity to examine microscope slides of Mesobiotus walteri from Binda \& Pilato's collection. I thank Professor Torbjørn Ekrem (Norwegian University of Science and Technology) for providing me with the unpublished DNA extraction protocol. I am grateful to Professor Łukasz Kaczmarek (Adam Mickiewicz University, Poznan, Poland) for permission to use his key for Mesobiotus species as a base for the key presented in this paper. I thank Peter Batson and Yuta Tamberg (University of Otago, Dunedin, New Zealand) for the linguistic review of the manuscript. This study was carried out with the use of equipment of the Core Facilities Centers: 'Culture Collection of Microorganisms', 'Centre for Molecular and Cell Technologies' and 'Centre for Microscopy and Microanalysis' of St. Petersburg State University. 


\section{References}

Abe W. \& Takeda M. 2000. Tardigrades from the Imperial Palace, Tokyo. Memoirs of the National Science Museum Tokyo 35: 165-177.

Abe W. \& Takeda M. 2005. Semiterrestrial tardigrades from the Tokiwamatsu Imperial Villa, Tokyo, Japan. Memoirs of the National Science Museum Tokyo 39: 503-510.

Bartels P.J., Apodaca J.J., Mora C. \& Nelson D.R. 2016. A global biodiversity estimate of a poorly known taxon: phylum Tardigrada. Zoological Journal of the Linnean Society 178 (4): 730-736.

https://doi.org/10.1111/zoj.12441

Bartsch I. 1989. Süsswasserbewohnende Halacariden und ihre Einordnung in das System der Halacaroidea (Acari). Acarologia 30 (3): 217-239.

Bartsch I. 1995a. A new subspecies of the freshwater halacarid mite Lobohalacarus weberi (Romijn and Viets) (Halacaridae, Acari) from a Southern Atlantic Ocean island. Annals of the Cape Provincial Museums, Natural History 19: 171-180.

Bartsch I. 1995b. Lobohalacarus subterraneus n. sp., a freshwater halacarid (Acari: Halacaridae) from New Zealand. New Zealand Journal of Zoology 22: 209-212.

https://doi.org/10.1080/03014223.1995.9518035

Bartsch I. 2008. Freshwater halacarid mites (Halacaridae: Prostigmata: Acari) from Tunesia, three new records and notes on geographical distribution of these species. Entomologische Mitteilungen aus dem Zoologischen Museum Hamburg 15 (178): 15-27.

Bartsch I. 2018. Freshwater halacarid mites (Acari: Halacaridae) from Madagascar - new records, keys and notes on distribution and biology. Bonn zoological Bulletin 67 (2): 79-99.

https://doi.org/10.20363/BZB-2018.67.2.079

Beasley C.W. \& Miller W.R. 2007. Tardigrada of Xinjiang Uygur Autonomous Region, China. Journal of Limnology 66 (S1): 49-55. https://doi.org/10.4081/jlimnol.2007.s1.49

Beasley C.W. \& Miller W.R. 2012. Additional Tardigrada from Hubei Province, China, with the description of Doryphoribius barbarae sp. nov. (Eutardigrada: Parachela: Hypsibiidae). Zootaxa 3170 (1): 55-63. https://doi.org/10.11646/zootaxa.3170.1.5

Bertolani R., Guidetti R., Marchioro T., Altiero T., Rebecchi L. \& Cesari M. 2014. Phylogeny of Eutardigrada: new molecular data and their morphological support lead to the identification of new evolutionary lineages. Molecular Phylogenetics and Evolution 76: 110-126.

https://doi.org/10.1016/j.ympev.2014.03.006

Czechowski P., Sands C.J., Adams B.J., D’Haese C.A., Gibson J.A.E., McInnes S.J. \& Stevens M.I. 2012. Antarctic Tardigrada: a first step in understanding molecular operational taxonomic units (MOTUs) and biogeography of cryptic meiofauna. Invertebrate Systematics 26: 526-538.

https://doi.org/10.1071/IS12034

Dabert M., Witalinski W., Kazmierski A., Olszanowski Z. \& Dabert J. 2010. Molecular phylogeny of acariform mites (Acari, Arachnida): strong conflict between phylogenetic signal and long-branch attraction artifacts. Molecular Phylogenetics and Evolution 56: 222-241.

https://doi.org/10.1016/j.ympev.2009.12.020

Dastych H. \& Harris J.M. 1995. A new species of the genus Macrobiotus from inland nunataks, Dronning Maud Land (Tardigrada). Entomologische Mitteilungen aus dem Zoologischen Museum Hamburg 11: $176-182$. 
Degma P., Bertolani R. \& Guidetti R. (2009-2020). Actual checklist of Tardigrada species. $37^{\text {th }}$ Edition: 03-07-2020. Available from https://doi.org/10.25431/11380_1178608 [accessed 24 Jul. 2020].

Edgar R.C. 2004. MUSCLE: multiple sequence alignment with high accuracy and high throughput. Nucleic Acids Research 32 (5): 1792-1797. https://doi.org/10.1093/nar/gkh340

Folmer O., Black M., Hoeh W., Lutz R. \& Vrijenhoek R. 1994. DNA primers for amplification of mitochondrial cytochrome c oxidase subunit I from diverse metazoan invertebrates. Molecular Marine Biology and Biotechnology 3 (5): 294-299.

Gąsiorek P., Stec D., Zawierucha K., Kristensen R.M. \& Michalczyk Ł. 2018. Revision of Testechiniscus Kristensen, 1987 (Heterotardigrada: Echiniscidae) refutes the polar-temperate distribution of the genus. Zootaxa 4472 (2): 261-297. https://doi.org/10.11646/zootaxa.4472.2.3

Gouy M., Guindon S. \& Gascuel O. 2010. SeaView version 4: a multiplatform graphical user interface for sequence alignment and phylogenetic tree building. Molecular Biology and Evolution 27 (2): 221224. https://doi.org/10.1093/molbev/msp259

Guidetti R., Gneuß E., Cesari M., Altiero T. \& Schill R.O. 2019. Life-history traits and description of the new gonochoric amphimictic Mesobiotus joenssoni (Eutardigrada: Macrobiotidae) from the island of Elba, Italy. Zoological Journal of the Linnean Society 188: 848-859.

https://doi.org/10.1093/zoolinnean/zlz077

Guil N., Jørgensen A. \& Kristensen R. 2019. An upgraded comprehensive multilocus phylogeny of the Tardigrada tree of life. Zoologica Scripta 48 (1): 120-137. https://doi.org/10.1111/zsc.12321

Harvey M.S. 1988. A new species of Lobohalacarus from Australia (Chelicerata: Acarina: Halacaridae). Memoirs of the Museum of Victoria 49: 363-365. https://doi.org/10.24199/j.mmv.1988.49.15

Itang L.A.M., Stec D., Mapalo M.A., Mirano-Bascos D. \& Michalczyk Ł. 2020. An integrative description of Mesobiotus dilimanensis, a new tardigrade species from the Philippines (Eutardigrada: Macrobiotidae: furciger group). Raffles Bulletin of Zoology 68: 19-31.

https://doi.org/10.26107/RBZ-2020-0003

Kaczmarek Ł. \& Michalczyk Ł. 2017. The Macrobiotus hufelandi group (Tardigrada) revisited. Zootaxa 4363 (1): 101-123. https://doi.org/10.11646/zootaxa.4363.1.4

Kaczmarek Ł., Cytan J., Zawierucha K., Diduszko D. \& Michalczyk Ł. 2014. Tardigrades from Peru (South America), with descriptions of three new species of Parachela. Zootaxa 3790 (2): 357-379.

https://doi.org/10.11646/zootaxa.3790.2.5

Kaczmarek Ł., Zawierucha K., Buda J., Stec D., Gawlak M., Michalczyk Ł. \& Roszkowska M. 2018. An integrative redescription of the nominal taxon for the Mesobiotus harmsworthi group (Tardigrada: Macrobiotidae) leads to descriptions of two new Mesobiotus species from Arctic. PLoS ONE 13 (10): e0204756. https://doi.org/10.1371/journal.pone.0204756

Kaczmarek Ł., Bartylak T., Stec D., Kulpa A., Kepel M., Kepel A. \& Roszkowska M. 2020. Revisiting the genus Mesobiotus Vecchi et al., 2016 (Eutardigrada, Macrobiotidae) - remarks, updated dichotomous key and an integrative description of new species from Madagascar. Zoologischer Anzeiger 287: 121146. https://doi.org/10.1016/j.jcz.2020.05.003

Kumar S., Stecher G. \& Tamura K. 2016. MEGA7: Molecular Evolutionary Genetics Analysis version 7.0 for bigger datasets. Molecular Biology and Evolution 33 (7): 1870-1874.

https://doi.org/10.1093/molbev/msw054

Mapalo M., Stec D., Mirano-Bascos D.M. \& Michalczyk Ł. 2016. Mesobiotus philippinicus sp. nov., the first limnoterrestrial tardigrade from the Philippines. Zootaxa 4126 (3): 411-426.

https://doi.org/10.11646/zootaxa.4126.3.6 
Mapalo M., Stec D., Mirano-Bascos D. \& Michalczyk Ł. 2017. An integrative description of a limnoterrestrial tardigrade from the Philippines, Mesobiotus insanis, new species (Eutardigrada: Macrobiotidae: harmsworthi group). Raffles Bulletin of Zoology 65: 440-454.

Maucci W. \& Durante Pasa M.V. 1980. Tardigradi muscicoli delle isole Andamane. Bollettino del Museo Civico di Storia Naturale di Verona 7: 281-291.

McInnes S.J., Michalczyk Ł. \& Kaczmarek Ł. 2017. Annotated zoogeography of non-marine Tardigrada. Part IV: Africa. Zootaxa 4284 (1): 1-74. https://doi.org/10.11646/zootaxa.4284.1.1

Meyer H.A., Tsaliki M. \& Hinton J.G. 2018. First records of water bears (Phylum Tardigrada) from Swaziland. African Invertebrates 59 (1): 47-53. https://doi.org/10.3897/AfrInvertebr.59.23191

Michalczyk Ł. \& Kaczmarek Ł. 2003. A description of the new tardigrade Macrobiotus reinhardti (Eutardigrada: Macrobiotidae, harmsworthi group) with some remarks on the oral cavity armature within the genus Macrobiotus Schultze. Zootaxa 331 (1): 1-24. https://doi.org/10.11646/zootaxa.331.1.1

Michalczyk Ł. \& Kaczmarek Ł. 2013. The Tardigrada Register: a comprehensive online data repository for tardigrade taxonomy. Journal of Limnology 72 (S1): e22.

https://doi.org/10.4081/jlimnol.2013.s1.e22

Michalczyk Ł., Wełnicz W., Frohme M. \& Kaczmarek Ł. 2012. Redescriptions of three Milnesium Doyère, 1840 taxa (Tardigrada: Eutardigrada: Milnesiidae), including the nominal species for the genus. Zootaxa 3154 (1): 1-20. https://doi.org/10.11646/zootaxa.3154.1.1

Middleton R.C. 2003. Tardigrades in southern Africa. African Journal of Ecology 41: 280-282. https://doi.org/10.1046/j.1365-2028.2003.00439.x

Mironov S.V., Dabert J. \& Dabert M. 2012. Anew feather mite species of the genus Proctophyllodes Robin, 1877 (Astigmata: Proctophyllodidae) from the Long-tailed Tit Aegithalos caudatus (Passeriformes: Aegithalidae) - morphological description with DNA barcode data. Zootaxa 3253 (1): 54-61.

https://doi.org/10.11646/zootaxa.3253.1.2

Pilato G. 1974. Tre nouve specie di Tardigradi muscicoli di Cina. Animalia 1: 59-68.

Pilato G. 1981. Analisi di nuovi caratteri nello studio degli Eutardigradi. Animalia 8 (1/3): 51-57.

Pilato G. \& Binda M.G. 2010. Definition of families, subfamilies, genera and subgenera of the Eutardigrada, and keys to their identification. Zootaxa 2404 (1): 1-54. https://doi.org/10.11646/zootaxa.2404.1.1

Pleijel F., Jondelius U., Norlinder E., Nygren A., Oxelman B., Schander C., Sundberg P. \& Thollesson M. 2008. Phylogenies without roots? A plea for the use of vouchers in molecular phylogenetic studies. Molecular Phylogenetics and Evolution 48 (1): 369-371. https://doi.org/10.1016/j.ympev.2008.03.024

Rossi G., Claps M. \& Ardohain D. 2009. Tardigrades from northwestern Patagonia (Neuquén Province, Argentina) with the description of three new species. Zootaxa 2095 (1): 21-36.

https://doi.org/10.11646/zootaxa.2095.1.3

Roszkowska M., Stec D., Gawlak M. \& Kaczmarek Ł. 2018. An integrative description of a new tardigrade species Mesobiotus romani sp. nov (Macrobiotidae; harmsworthi group) from the Ecuadorian Pacific coast. Zootaxa 4450 (5): 550-564. https://doi.org/10.11646/zootaxa.4450.5.2

Sands C.J., McInnes S.J., Marley N.J., Goodall-Copestake W., Convey P. \& Linse K. 2008. Phylum Tardigarda: an "individual" approach. Cladistics 24: 1-18.

https://doi.org/10.1111/j.1096-0031.2008.00219.x

Stec D. 2019. Mesobiotus datanlanicus sp. nov., a new tardigrade species (Macrobiotidae: Mesobiotus harmsworthi group) from Lâm Đồng Province in Vietnam. Zootaxa 4679 (1): 164-180.

https://doi.org/10.11646/zootaxa.4679.1.10 
Stec D. \& Kristensen R.M. 2017. An integrative description of Mesobiotus ethiopicus sp. nov. (Tardigrada: Eutardigrada: Parachela: Macrobiotidae: harmsworthi group) from the northern Afrotropic region. Turkish Journal of Zoology 41: 800-811. https://doi.org/10.3906/zoo-1701-47

Stec D., Smolak R., Kaczmarek Ł. \& Michalczyk Ł. 2015. An integrative description of Macrobiotus paulinae sp. nov. (Tardigrada: Eutardigrada: Macrobiotidae: hufelandi group) from Kenya. Zootaxa 4052 (5): 501-526. https://doi.org/10.11646/zootaxa.4052.5.1

Stec D., Gąsiorek P., Morek W., Kosztyła P., Zawierucha K., Michno K., Kaczmarek Ł., Prokop Z.M. \& Michalczyk Ł. 2016. Estimating optimal sample size for tardigrade morphometry. Zoological Journal of the Linnean Society 178 (4): 776-784. https://doi.org/10.1111/zoj.12404

Stec D., Zawierucha K. \& Michalczyk Ł. 2017. An integrative description of Ramazzottius subanomalus (Biserov, 1985) (Tardigrada) from Poland. Zootaxa 4300 (3): 403-420.

https://doi.org/10.11646/zootaxa.4300.3.4

Stec D., Morek W., Gąsiorek P. \& Michalczyk Ł. 2018a. Unmasking hidden species diversity within the Ramazzottius oberhaeuseri complex, with an integrative redescription of the nominal species for the family Ramazzottiidae (Tardigrada: Eutardigrada: Parachela). Systematics and Biodiversity 16 (4): 357-376. https://doi.org/10.1080/14772000.2018.1424267

Stec D., Roszkowska M., Kaczmarek Ł. \& Michalczyk Ł. 2018b. An integrative description of a population of Mesobiotus radiatus (Pilato, Binda \& Catanzaro, 1991) from Kenya. Turkish Journal of Zoology 42: 523-540. https://doi.org/10.3906/zoo-1802-43

Stec D., Kristensen R.M. \& Michalczyk Ł. 2020. An integrative description of Minibiotus ioculator sp. nov. from the Republic of South Africa with notes on Minibiotus pentannulatus Londoño et al., 2017 (Tardigrada: Macrobiotidae). Zoologischer Anzeiger 286: 117-134.

https://doi.org/10.1016/j.jcz.2020.03.007

Tumanov D.V. 2018a. Hypsibius vaskelae, a new species of Tardigrada (Eutardigrada, Hypsibiidae) from Russia. Zootaxa 4399 (3): 434-442. https://doi.org/10.11646/zootaxa.4399.3.12

Tumanov D.V. 2018b. Mesobiotus nikolaevae sp. n. (Eutardigrada: Macrobiotidae), a new species of Tardigrada from Croatia. Invertebrate Zoology 15 (4): 402-419.

https://doi.org/10.15298/invertzool.15.4.08

Tumanov D.V. \& Pilato G. 2019. A new species of Eutardigrade (Macrobiotidae) from New Zealand. Zootaxa 4603 (3): 537-548. https://doi.org/10.11646/zootaxa.4603.3.6

Utsugi K. 1988. Tardigrades in Hokkaido area. Zoological Science 5 (4): 1335.

Vecchi M., Cesari M., Bertolani R., Jönsson K.I., Rebecchi L. \& Guidetti R. 2016. Integrative systematic studies on tardigrades from Antarctica identify new genera and new species within Macrobiotoidea and Echiniscoidea. Invertebrate Systematics 30 (4): 303-322. https://doi.org/10.1071/IS15033

Manuscript received: 28 August 2020

Manuscript accepted: 24 September 2020

Published on: 4 December 2020

Topic editor: Rudy Jocqué

Section editor: Daniel Piotr Stec

Desk editor: Pepe Fernández 
Printed versions of all papers are also deposited in the libraries of the institutes that are members of the EJT consortium: Muséum national d'histoire naturelle, Paris, France; Meise Botanic Garden, Belgium; Royal Museum for Central Africa, Tervuren, Belgium; Royal Belgian Institute of Natural Sciences, Brussels, Belgium; Natural History Museum of Denmark, Copenhagen, Denmark; Naturalis Biodiversity Center, Leiden, the Netherlands; Museo Nacional de Ciencias Naturales-CSIC, Madrid, Spain; Real Jardín Botánico de Madrid CSIC, Spain; Zoological Research Museum Alexander Koenig, Bonn, Germany; National Museum, Prague, Czech Republic.

\section{Supplementary material}

Supplementary file 1. DNA extraction protocol. https://doi.org/10.5852/ejt.2020.726.1179.3271

Supplementary file 2. Raw morphometric data for Mesobiotus anastasiae sp. nov. https://doi.org/10.5852/ejt.2020.726.1179.3273

Supplementary file 3. Matrices of p-distances for species of Mesobiotus Vecchi, Cesari, Bertolani, Jönsson \& Guidetti, 2016. https://doi.org/10.5852/ejt.2020.726.1179.3275 
Appendix 1 (continued on next page). Complete list of sequences used for molecular comparisons between the new Mesobiotus species described in this study and all other species of the genus Mesobiotus for which homologous DNA sequences are currently available.

\begin{tabular}{|c|c|c|c|}
\hline Gene & Species & Accession number & Source \\
\hline \multirow[t]{16}{*}{ COI } & Mesobiotus anastasiae sp. nov. & МT904513 & this study \\
\hline & Mesobiotus cf. barabanovi (Tumanov, 2005) & MN313170 & Kaczmarek et al. 2020 \\
\hline & Mesobiotus datanlanicus Stec, 2019 & MK578905 & Stec 2019 \\
\hline & Mesobiotus dilimanensis Itang et al., 2020 & MN257047 & Itang et al. 2020 \\
\hline & Mesobiotus ethiopicus Stec \& Kristensen, 2017 & MF678794 & Stec \& Kristensen 2017 \\
\hline & Mesobiotus fiedleri Kaczmarek et al., 2020 & MH676056 & Kaczmarek et al. 2020 \\
\hline & Mesobiotus furciger (Murray, 1907) & $\begin{array}{l}\text { JX865306, } \\
\text { JX865308, } \\
\text { JX865314, }\end{array}$ & Czechowski et al. 2012 \\
\hline & Mesobiotus harmsworthi (Murray, 1907) & $\begin{array}{l}\text { MH195150, } \\
\text { MH195151 }\end{array}$ & Kaczmarek et al. 2018 \\
\hline & Mesobiotus hilariae Vecchi et al., 2016 & KT226108 & Vecchi et al. 2016 \\
\hline & Mesobiotus insanis Mapalo et al., 2017 & MF441491 & Mapalo et al. 2017 \\
\hline & Mesobiotus occultatus Kaczmarek et al., 2018 & MH195152 & Kaczmarek et al. 2018 \\
\hline & Mesobiotus philippinicus Mapalo et al., 2016 & KX129796 & Mapalo et al. 2016 \\
\hline & Mesobiotus radiatus (Pilato et al., 1991) & MH195148 & Stec et al. $2018 b$ \\
\hline & Mesobiotus romani Roszkowska et al., 2018 & MH195149 & Roszkowska et al. 2018 \\
\hline & Mesobiotus gr. furciger & MH195153 & Kaczmarek et al. 2018 \\
\hline & Mesobiotus gr. harmsworthi & MH195154 & Kaczmarek et al. 2018 \\
\hline \multirow[t]{15}{*}{ 18S rRNA } & Mesobiotus anastasiae sp. nov. & MT903468 & this study \\
\hline & Mesobiotus cf. barabanovi (Tumanov, 2005) & MN310392 & Kaczmarek et al. 2020 \\
\hline & Mesobiotus datanlanicus Stec, 2019 & MK584659 & Stec 2019 \\
\hline & Mesobiotus dilimanensis Itang et al., 2020 & MN257048 & Itang et al. 2020 \\
\hline & Mesobiotus ethiopicus Stec \& Kristensen, 2017 & MF678793 & Stec \& Kristensen 2017 \\
\hline & Mesobiotus fiedleri Kaczmarek et al., 2020 & MH681585 & Kaczmarek et al. 2020 \\
\hline & Mesobiotus furciger (Murray, 1907) & $\begin{array}{l}\text { EU266927, } \\
\text { EU266928, } \\
\text { EU266929 }\end{array}$ & Sands et al. 2008 \\
\hline & Mesobiotus harmsworthi (Murray, 1907) & MH197146 & Kaczmarek et al. 2018 \\
\hline & Mesobiotus hilariae Vecchi et al., 2016 & $\begin{array}{l}\text { KT226068, } \\
\text { KT226069, } \\
\text { KT226070, } \\
\text { KT226071 }\end{array}$ & Vecchi et al. 2016 \\
\hline & Mesobiotus insanis Mapalo et al., 2017 & MF441488 & Mapalo et al. 2017 \\
\hline & Mesobiotus cf. mottai (Binda \& Pilato, 1994) & KT226072 & Vecchi et al. 2016 \\
\hline & Mesobiotus occultatus Kaczmarek et al., 2018 & MH197147 & Kaczmarek et al. 2018 \\
\hline & Mesobiotus philippinicus Mapalo et al., 2016 & KX129793 & Mapalo et al. 2016 \\
\hline & Mesobiotus polaris (Murray, 1910) & $\begin{array}{l}\text { KT226075, } \\
\text { KT226076, } \\
\text { KT226077, } \\
\text { KT226078 }\end{array}$ & Vecchi et al. 2016 \\
\hline & Mesobiotus radiatus (Pilato et al., 1991) & MH197153 & Stec et al. 2018b \\
\hline
\end{tabular}


Appendix 1 (continued).

\begin{tabular}{|c|c|c|c|}
\hline Gene & Species & Accession number & Source \\
\hline & Mesobiotus romani Roszkowska et al., 2018 & MH197158 & Roszkowska et al. 2018 \\
\hline & Mesobiotus gr. furciger & MH197148 & Kaczmarek et al. 2018 \\
\hline & Mesobiotus gr. harmsworthi & MH197149 & Kaczmarek et al. 2018 \\
\hline & Mesobiotus gr. harmsworthi & $\begin{array}{l}\text { KT226073, } \\
\text { KT226074 }\end{array}$ & Vecchi et al. 2016 \\
\hline & Mesobiotus gr. harmsworthi & $\begin{array}{l}\text { HQ604967, } \\
\text { HQ604968, } \\
\text { HQ604969, } \\
\text { HQ604970 }\end{array}$ & Bertolani et al. 2014 \\
\hline \multirow[t]{13}{*}{ 28S rRNA } & Mesobiotus anastasiae sp. nov. & MT903612 & this study \\
\hline & Mesobiotus cf. barabanovi (Tumanov, 2005) & MN310388 & Kaczmarek et al. 2020 \\
\hline & Mesobiotus datanlanicus Stec, 2019 & MK584658 & Stec 2019 \\
\hline & Mesobiotus dilimanensis Itang et al., 2020 & MN257049 & Itang et al. 2020 \\
\hline & Mesobiotus ethiopicus Stec \& Kristensen, 2017 & MF678792 & Stec \& Kristensen 2017 \\
\hline & Mesobiotus fiedleri Kaczmarek et al., 2020 & MH681693 & Kaczmarek et al. 2020 \\
\hline & Mesobiotus harmsworthi (Murray, 1907) & MH197264 & Kaczmarek et al. 2018 \\
\hline & Mesobiotus insanis Mapalo et al., 2017 & MF441489 & Mapalo et al. 2017 \\
\hline & Mesobiotus philippinicus Mapalo et al., 2016 & KX129794 & Mapalo et al. 2016 \\
\hline & Mesobiotus radiatus (Pilato et al., 1991) & MH197152 & Stec et al. $2018 \mathrm{~b}$ \\
\hline & Mesobiotus romani Roszkowska et al., 2018 & MH197151 & Roszkowska et al. 2018 \\
\hline & Mesobiotus gr. furciger & MH197265 & Kaczmarek et al. 2018 \\
\hline & Mesobiotus gr. harmsworthi. & MH197266 & Kaczmarek et al. 2018 \\
\hline \multirow[t]{14}{*}{ ITS-2 } & Mesobiotus anastasiae sp. nov. & MT903470 & this study \\
\hline & Mesobiotus cf. barabanovi & MN310390 & Kaczmarek et al. 2020 \\
\hline & Mesobiotus datanlanicus Stec, 2019 & MK584657 & Stec 2019 \\
\hline & Mesobiotus dilimanensis Itang et al., 2020 & MN257050 & Itang et al. 2020 \\
\hline & Mesobiotus ethiopicus Stec \& Kristensen, 2017 & MN122776 & Stec \& Kristensen 2017 \\
\hline & Mesobiotus fiedleri Kaczmarek et al., 2020 & MH681724 & Kaczmarek et al. 2020 \\
\hline & Mesobiotus harmsworthi (Murray, 1907) & MH197154 & Kaczmarek et al. 2018 \\
\hline & Mesobiotus insanis Mapalo et al., 2017 & MF441490 & Mapalo et al. 2017 \\
\hline & Mesobiotus occultatus Kaczmarek et al., 2018 & MH197155 & Kaczmarek et al. 2018 \\
\hline & Mesobiotus philippinicus Mapalo et al., 2016 & KX129795 & Mapalo et al. 2016 \\
\hline & Mesobiotus radiatus (Pilato et al., 1991) & $\begin{array}{l}\text { MH197267, } \\
\text { MH197268 }\end{array}$ & Stec et al. $2018 \mathrm{~b}$ \\
\hline & Mesobiotus romani Roszkowska et al., 2018 & MH197150 & Roszkowska et al. 2018 \\
\hline & Mesobiotus gr. furciger & MH197156 & Kaczmarek et al. 2018 \\
\hline & Mesobiotus gr. harmsworthi & MH197157 & Kaczmarek et al. 2018 \\
\hline
\end{tabular}


Appendix 2. Key to the species of the genus Mesobiotus Vecchi, Cesari, Bertolani, Jönsson \& Guidetti, 2016.

A key to the Mesobiotus species was published recently (Kaczmarek et al. 2020). Unfortunately, two species (M. nikolaevae Tumanov, 2018 and M. helenae Tumanov \& Pilato, 2019) were not included in this work, and three additional species (M. datanlanicus Stec, 2019, M. dilimanensis Itang, Stec, Mapalo, Mirano-Bascos \& Michalczyk, 2020 and M. joenssoni Guidetti, Gneuß, Cesari, Altiero \& Schill, 2019) are not present because the key predates their descriptions. Further, some minor inaccuracies in the key were revealed. Here I present an updated key to the species of the genus Mesobiotus, including all abovementioned omitted species, as well as the new species described here. The key is based on the version published by Kaczmarek et al. (2020). Mesobiotus meridionalis (Richters, 1909) nom. inq., M. polaris (Murray, 1910) nom. inq., M. stellaris (du Bois-Reymond Marcus, 1944) nom. inq. and M. armatus (Pilato \& Binda, 1996) nom. inq. were excluded from the key, following Kaczmarek et al. (2020).

1. Dorsal cuticle with sculptured surface (visible in $\mathrm{PhC}$ as granulation or thin reticulate pattern) or with pores or stripes of pigmentation

- Cuticle smooth (except for minute regular granulation visible only in SEM) ................................11

2. Stripes of pigmentation present

M. baltatus (McInnes, 1991)

- Stripes of pigmentation absent

3. First band in oral cavity present

- First band in oral cavity absent or not visible in PCM M. perfidus (Pilato \& Lisi, 2009)

4. Cuticle with pores without granulation on the body surface or on legs, oral cavity armature without longitudinally elongated teeth in the second band, egg processes in shape of cones with long slender endings, egg processes with "bubbles", egg processes bases without crown of thickenings

M. krynauwi (Dastych \& Harris, 1995)

- Cuticle with sculpture, visible in $\mathrm{PhC}$ as granulation or dot-like sculpture, or with thin reticulate pattern, without pores

5. Cuticular sculpture consists of relatively large granules, well-visible in $\mathrm{PhC}$ (granules size $\geq 1 \mu \mathrm{m}$ ) in the caudal region of the dorsal body surface

- Cuticular sculpture without large granules, with fine dot-like sculpture poorly visible in LM or with thin reticulate pattern only

6. Granules of the cuticular sculpture are present from the level of the third legs to the posterior end of the animal, $p t$ of stylet supports 72.41-83.64, egg processes $27-36 \mu \mathrm{m}$ high, with collar and large pores above it ....................................... joenssoni Guidetti, Gneuß, Cesari, Altiero \& Schill, 2019

- Granules of the cuticular sculpture are present only on the caudal extremity of the body, pt of stylet supports ca 85.4, maximal height of egg processes is $19 \mu \mathrm{m}$

M. arguei (Pilato \& Sperlinga, 1975)

7. Cuticular sculpture appears in $\mathrm{PhC}$ as thin reticulate pattern, oral cavity armature without longitudinally elongated teeth in the second band, with one row of elongated teeth in the first band, egg processes with collar and large pores above it M. anastasiae sp. nov.

- Cuticular sculpture consists of fine granules or tubercles, poorly visible in $\mathrm{PhC}$, without reticular pattern, oral cavity armature with longitudinally elongated teeth in the second band

8. Egg shell porous M. sicheli (Binda, Pilato \& Lisi, 2005)

- Egg shell different 
9. Egg shell surface with reticular sculpture, egg processes smooth, number of egg processes on the circumference 22 or more, width of egg processes bases less than $8.9 \mu \mathrm{m}$

M. contii (Pilato \& Lisi, 2006)

- Egg shell surface smooth, egg processes with reticular design, number of egg processes on the circumference 21 or less, width of egg processes bases $8.9 \mu \mathrm{m}$ or more 10

10. Lunules under claws IV smooth, eyes absent, the egg processes bases elongated into long stripes which forms the areolation (5-7 areoles around each egg process) on the egg shell surface (full areolation)

M. pseudonuragicus (Pilato, Binda \& Lisi, 2004)

- Lunules under claws IV with indented margin, eyes present, areolation on the egg surface absent, egg process bases with crown of thickenings ........ pseudocoronatus (Pilato, Binda \& Lisi, 2006)

11. The egg processes in shape of flat hemispherical domes

- The egg processes in shape of cones or "mammillate-like domes"

12. The egg surface with reticular sculpture, egg processes bases without crown of thickenings

M. montanus (Murray, 1910)

- The egg surface without reticular sculpture, egg processes bases with crown of thickenings and wrinkles M. mottai (Binda \& Pilato, 1994)

13. The egg processes "mammillate-like domes"

- The egg processes in shape of cones

14. The egg processes bases with finger-like projections, egg processes with reticular design and without additional, small hemispherical projections on the top, number of egg processes on the circumference 16 or more, width of egg processes bases more than $11.0 \mu \mathrm{m}$

M. peterseni (Maucci, 1991)

- The egg processes bases with finger-like projections, egg processes without reticular design and with additional, small hemispherical projections on the top, number of egg processes on the circumference 15 or less, width of egg processes bases less than $7.0 \mu \mathrm{m}$

M. Iusitanicus (Maucci \& Durante Pasa, 1984)

15. Egg processes with basal collar, egg shell with polygonal relief

M. mauccii (Pilato, 1974)

- Egg processes without collar, egg shell without polygonal relief

16. The egg processes in shape of truncated cones M. zhejiangensis (Yin, Wang \& Li, 2011)

- The egg processes different

17. The egg processes bases elongated into long stripes that form the areolation on the egg shell surface (full areolation)

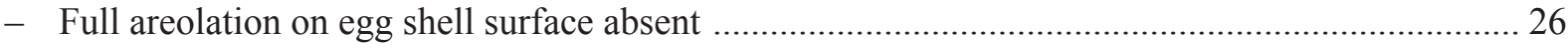

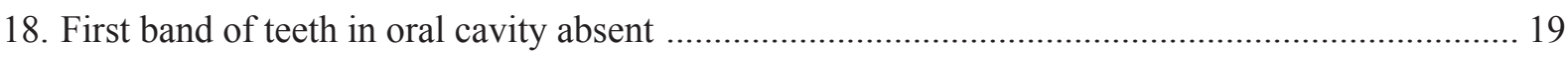

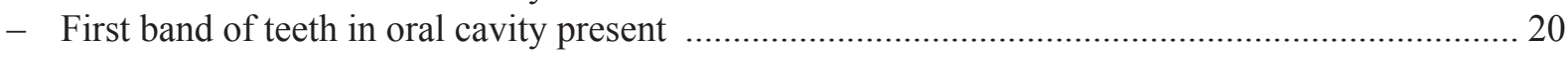

19. Lunules under claws IV smooth, egg processes in shape of cones with long slender endings

M. ovostriatus (Pilato \& Patanè, 1998)

- Lunules under claws IV indented, egg processes in shape of sharp wide cones M. hilariae Vecchi, Cesari, Bertolani, Jøonsson, Rebecchi \& Guidetti, 2016

20. Egg processes with terminal filaments 21

- Egg processes without terminal filaments 22 
21. Eyes absent, macroplacoid length sequence $(2<1<3)$, process apices divided into at least 15 filaments

M. insanis Mapalo, Stec, Mirano-Bascos \& Michalczyk, 2017

- Eyes present, macroplacoid length sequence $(2<1=3)$, process apices divided into 2-5 filaments M. nuragicus (Pilato \& Sperlinga, 1975)

22. Egg processes are usually terminated by a multifurcated crown of several finger-shaped appendages, which often are terminated by short spines

M. datanlanicus Stec, 2019

- Egg processes without crown of appendages at the top 23

23. Egg processes in shape of cones with long slender endings

..M. barbarae (Kaczmarek, Michalczyk \& Degma, 2007)

- Egg processes sharp, narrow or wide cones

24. Granulation on legs absent, egg processes in the shape of sharp wide cones, height of egg processes less than $16.0 \mu \mathrm{m}$ M. neuquensis (Rossi, Claps \& Ardohain, 2009)

- Granulation on legs present, egg processes in the shape of sharp narrow cones, height of egg processes more than $24.0 \mu \mathrm{m}$

25. The $p t$ of stylet supports less than 75.0, six areoles around each egg process, height of egg processes less than $35.0 \mu \mathrm{m}$, width of egg processes bases less than $22.0 \mu \mathrm{m}$

M. hieronimi (Pilato \& Claxton, 1988)

- The $p t$ of stylet supports more than 77.0, sixteen areoles around each egg process, height of egg processes more than $41.0 \mu \mathrm{m}$, width of egg processes bases more than $27.0 \mu \mathrm{m}$

M. pseudoliviae (Pilato \& Binda, 1996)

26. Egg processes bases elongated into long stripes, which form the semi-areolation (the branches at least in some cases not connected to each other)

- Egg processes bases different 31

27. Eyes absent, egg processes with filaments M. ethiopicus Stec \& Kristensen, 2017

- Eyes present, egg processes without filaments 28

28. Additional teeth in oral cavity armature present, egg processes with "bubbles" 29

- Additional teeth in oral cavity armature absent, egg processes without "bubbles" 30

29. Claws IV with large, protruding accessory points, egg processes with reticular design, number of egg processes on the circumference 11-12

M. harmsworthi (Murray, 1907)

- Large and protruding accessory points on claws IV absent, egg processes without reticular design, number of egg processes on the circumference 15-24 M. blocki (Dastych, 1984)

30. Granulation on legs I-III absent, egg processes in shape of cones with long slender endings, number of egg processes on the circumference ca 20

M. barabanovi (Tumanov, 2005)

- Granulation on legs I-III present, egg processes in shape of sharp wide cones, number of egg processes on the circumference 10-12

M. skoracki Kaczmarek, Zawierucha, Buda, Stec, Gawlak, Michalczyk \& Roszkowska, 2018

31. Egg processes with finger-like projections, i.e., egg processes bases elongated into long stripes, but never connected to each other

- Egg processes without finger-like projections 39

32. Egg processes in shape of cones with long slender endings 33 
- Egg processes in the shape of sharp, narrow or wide cones

33. Egg processes with "bubbles" and flexible filaments in apical part, height of egg processes less than $13.0 \mu \mathrm{m}$ M. pseudoblocki Roszkowska, Stec, Ciobanu \& Kaczmarek, 2016

- Egg processes without "bubbles" or flexible filaments in apical part, height of egg processes more than $20.0 \mu \mathrm{m}$

34. Eyes present, number of egg processes on the circumference 6-8, height of egg processes $50.0 \mu \mathrm{m}$ or more

M. liviae (Ramazzotti, 1962)

- Eyes absent, number of egg processes on the circumference ca 12, height of egg processes ca $21.0 \mu \mathrm{m}$

M. snaresensis (Horning, Schuster \& Grigarick, 1978)

35. Egg processes with "bubbles", in shape of sharp narrow cones

- Egg processes without "bubbles", in shape of sharp wide cones

36. Eyes absent, additional teeth in oral cavity absent

M. tehuelchensis (Rossi, Claps \& Ardohain, 2009)

- Eyes present, additional teeth in oral cavity present

37. Finger-like projections very small, present only on some processes and irregularly distributed

M. reinhardti (Michalczyk \& Kaczmarek, 2003)

- Six, large and regularly distributed finger-like projections present on all processes

M. szeptyckii (Kaczmarek \& Michalczyk, 2009)

38. Eyes and first band of teeth in oral cavity present, $p t$ of stylet supports 77.0 or more, egg full diameter (with processes) 100.0-116.0 $\mu \mathrm{m}$, number of egg processes on the circumference 8-9, height of egg processes $12.0-24.0 \mu \mathrm{m}$

M. erminiae (Binda \& Pilato, 1999)

- Eyes absent, first band of teeth in oral cavity absent or not visible in PCM, $p t$ of stylet supports 75.5 or less, egg full diameter (with processes) 88.0-92.0 $\mu \mathrm{m}$, number of egg processes on the circumference $12-15$, height of egg processes $9.0-11.0 \mu \mathrm{m}$ M. diguensis (Pilato \& Lisi, 2009)

39. Egg processes with reticular design 40

- Egg processes smooth or with refracting areas 56

40. First band of teeth in oral cavity absent or not visible in PCM ..................................................... 41

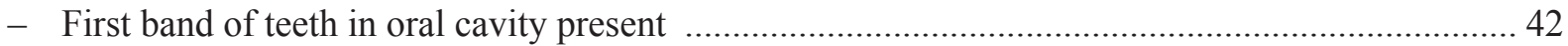

41. Eyes present, lunules under claws IV indented, granulation on legs I-III present, number of egg processes on the circumference 15-17

M. philippinicus Mapalo, Stec, Mirano-Bascos \& Michalczyk, 2016

- Eyes absent, lunules under claws IV smooth, granulation on legs I-III absent, number of egg processes on the circumference 11-12

M. pseudopatiens Kaczmarek \& Roszkowska, 2016

42. Egg processes with terminal filaments (at least a significant part of them) …............................... 43

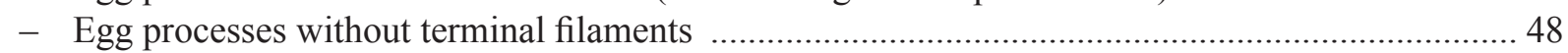

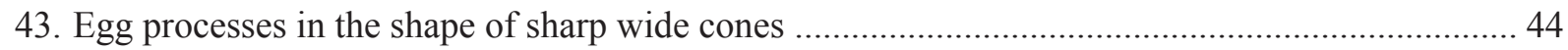

- Egg processes in the shape of cones with long, slender endings ................................................. 45

44. Egg processes with bunch of short filaments, number of egg processes on the circumference 10-12, width of egg processes bases $14.5-22.5 \mu \mathrm{m}$ M. radiatus (Pilato, Binda \& Catanzaro, 1991) 
- Egg processes with few long filaments, number of egg processes on the circumference 15-17, width of egg processes bases $10.0-14.0 \mu \mathrm{m}$ M. dimentmani (Pilato, Lisi \& Binda, 2010)

45. Lunules under claws IV without indentation M. nikolaevae Tumanov, 2018

- Lunules under claws IV indented 46

46. Egg processes bases without distinct crown of thickenings, processes are connected with very thin ridges M. diffusus (Binda \& Pilato, 1987)

- Egg processes bases with distinct crown of thickenings, egg surface between processes with dots and wrinkles

47. Eyes present, lunules under claws IV with 4-5 denticles, egg processes tips sometimes trifurcated

M. wuzhishanensis (Yin, Wang \& Li, 2011)

- Eyes absent, lunules under claws IV with more than 5 denticles, egg processes tips never trifurcated ............................................... romani Roszkowska, Stec, Gawlak \& Kaczmarek, 2018

48. Egg processes in the shape of sharp wide cones

- Egg processes in the shape of cones with long, slender endings

49. Lunules under claws IV indented M. simulans (Pilato, Binda, Napolitano \& Moncada, 2000)

- Lunules under claws IV smooth

50. Additional teeth in oral cavity present, egg bare diameter (without processes) 55.0 or less, egg full diameter (with processes) $71.0 \mu \mathrm{m}$ or less, width of egg processes bases less than 10.5

M. coronatus (De Barros, 1942)

- Additional teeth in oral cavity absent, egg bare diameter (without processes) 59.0 or more, egg full diameter (with processes) $73.0 \mu \mathrm{m}$ or more, width of egg processes bases 11.1 or more 51

51. The basal tract of posterior and anterior claws IV much longer, primary and secondary branches forming an almost $90^{\circ}$ angle (Pilato et al., 2014: fig. 1d)

M. insuetus (Pilato, Sabella \& Lisi, 2014)

- Typical Mesobiotus claws IV 52

52. Eyes absent, macroplacoid length sequence $(2<3<1)$, additional teeth in oral cavity absent, height of egg processes 8-16 $\mu \mathrm{m}$ M. patiens (Pilato, Binda, Napolitano \& Moncada, 2000)

- Eyes present, macroplacoid length sequence $(2<3 \leq 1)$, with additional teeth in the ventral portion of the oral cavity, height of egg processes 14.1-21.8 $\mu \mathrm{m}$

.....M. occultatus Kaczmarek, Zawierucha, Buda, Stec, Gawlak, Michalczyk \& Roszkowska, 2018

53. Egg shell porous, egg processes bases without crown of thickenings, height of egg processes $22.0 \mu \mathrm{m}$ or more, width of egg processes $17.0 \mu \mathrm{m}$ or more M. altitudinalis (Biserov, 1997-98)

- Egg shell smooth or with dots and/or wrinkles, egg processes bases with crown of thickenings, height of egg processes $16.5 \mu \mathrm{m}$ or less, width of egg processes $15.5 \mu \mathrm{m}$ or less

54. Egg processes consists of wide short conical basal part very distinctly separated from the apical part in form of a thin long spine with poorly visible internal structure, number of egg processes on the circumference $27-32$

M. binieki (Kaczmarek, Gołdyn, Prokop \& Michalczyk, 2011)

- Egg processes with less abruptly separated basal and apical parts, apical part with well visible internal "bubbles", number of egg processes on the circumference less than 23 
55. Number of egg processes on the circumference ca 12, height of egg processes 15.2-16.2 $\mu \mathrm{m}$, with well visible reticular design of the egg processes, apical parts of egg processes rigid and never subdivided, egg surface with radial ridges M. rigidus (Pilato \& Lisi, 2006)

- Number of egg processes on the circumference ca 22, height of egg processes $11.0 \mu \mathrm{m}$, with faint and almost invisible reticular design of the egg processes, apical parts of egg processes flexible and rarely bifurcated, egg surface smooth M. helenae Tumanov \& Pilato, 2019

56. The egg processes in the shape of rough cones, egg processes bases smooth

M. kovalevi (Tumanov, 2004)

- The egg processes in the shape of branched or sharp wide cones, egg processes bases with crown of thickenings or wrinkles

57. The egg processes in the shape of sharp wide cones, the egg shell surface without pores or reticular sculpture

M. australis (Pilato \& D’Urso, 1976)

- The egg processes in the shape of branched cones, the egg shell surface porous or with reticular

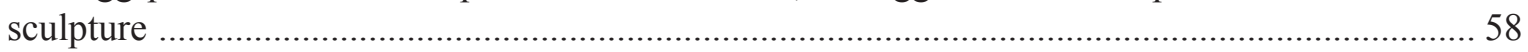

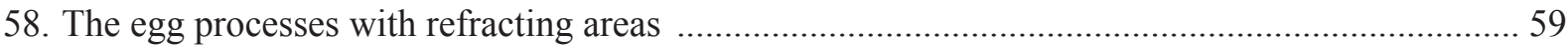

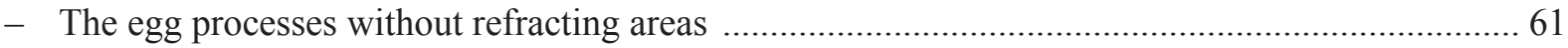

59. Bases of egg processes without band of pores, large and numerous refracting areas visible on the apical part of all processes M. furciger (Murray, 1907)

- Bases of egg processes with band of pores, small and single refracting areas present only on some processes

60. Apical parts of egg processes always divided into 2-4 branches, height of egg processes ca $15.0 \mu \mathrm{m}$, $p t$ of buccal tube width $22.8-25.4$

M. pilatoi (Binda \& Rebecchi, 1992)

- At least some of apical part of egg processes not divided, height of egg processes 8.5-13.1 $\mu \mathrm{m}, p t$ of buccal tube width $16.5-18.6$

M. fiedleri Kaczmarek, Bartylak, Stec, Kulpa, M. Kepel, A. Kepel \& Roszkowska, 2020

61. The egg shell surface with reticular sculpture or ridges, without pores

- The egg shell surface porous

62. The egg processes in the shape of branched cones with long slender endings, the egg shell surface with ridges radiating from process bases, only sometimes resembling reticulate pattern, height of egg processes 10.7-11.8 $\mu \mathrm{m}$, width of egg processes 7.4-10.0 $\mu \mathrm{m}$

M. siamensis (Tumanov, 2006)

- The egg processes in the shape of branched cones, the egg shell surface with clearly reticular sculpture, height of egg processes less than $10.0 \mu \mathrm{m}$, width of egg processes usually less than 7.0 $\mu \mathrm{m}$ (up to 7.5 in M. dilimanensis)

63. The $p t$ of stylet supports less than 76.5, egg processes sparsely distributed over the egg surface, number of egg processes on the circumference ca 17, egg processes with relatively long branches, nearly equal in length to the basal part, with multiple bifurcations, height of egg processes 4.7$4.8 \mu \mathrm{m}$ M. divergens (Binda, Pilato \& Lisi, 2005)

- The $p t$ of stylet supports more than 77.0, egg processes densely distributed over the egg surface, egg processes with relatively short branches, distinctly shorter than the basal part, height of egg processes usually exceeds $4.8 \mu \mathrm{m}$ 
64. Additional teeth in oral cavity absent, granulation on legs I-III present, $p t$ of the buccal tube external width 14.0-17.4, number of egg processes on the circumference 18-24

M. dilimanensis Itang, Stec, Mapalo, Mirano-Bascos \& Michalczyk, 2020

- Additional teeth in oral cavity present, granulation on legs I-III absent, $p t$ of the buccal tube external width 17.9-19.6, number of egg processes on the circumference 27-30

65. Egg processes divided close to or at the top, number of egg processes on the circumference ca 25 , width of egg processes $7.3-7.8 \mu \mathrm{m}$

M. orcadensis (Murray, 1907)

- Egg processes begin to divide in the middle of their length, number of egg processes on the circumference 21-23, width of egg processes $8.4-9.5 \mu \mathrm{m}$

M. aradasi (Binda, Pilato \& Lisi, 2005) 